University of Louisville

ThinkIR: The University of Louisville's Institutional Repository

$12-2012$

\title{
Combating the sophomore slump through peer-mentoring among African American students at predominantly white institutions.
}

Tiffany Christina Evans

University of Louisville

Follow this and additional works at: https://ir.library.louisville.edu/etd

\section{Recommended Citation}

Evans, Tiffany Christina, "Combating the sophomore slump through peer-mentoring among African American students at predominantly white institutions." (2012). Electronic Theses and Dissertations. Paper 411.

https://doi.org/10.18297/etd/411

This Master's Thesis is brought to you for free and open access by ThinkIR: The University of Louisville's Institutional Repository. It has been accepted for inclusion in Electronic Theses and Dissertations by an authorized administrator of ThinkIR: The University of Louisville's Institutional Repository. This title appears here courtesy of the author, who has retained all other copyrights. For more information, please contact thinkir@louisville.edu. 
COMBATING THE SOPHOMORE SLUMP THROUGH PEER-MENTORING AMONG AFRICAN AMERICAN STUDENTS AT PREDOMINATELY WHITE INSTITUTIONS

\author{
By \\ Tiffany Christina Evans \\ B.A., University of Louisville, 2009

\begin{abstract}
A Thesis
Submitted to the Faculty of the

College of Arts and Sciences of the University of Louisville in Partial Fulfillment of the Requirements

for the Degree of
\end{abstract}

Master of Arts

Department of Pan-African Studies

University of Louisville

Louisville, Kentucky

December 2012 
COMBATING THE SOPHOMORE SLUMP THROUGH PEER-MENTORING AMONG AFRICAN AMERICAN STUDENTS AT PREDOMINANTLY WHITE INSTITUTIONS

By

Tiffany Christina Evans

B.A., University of Louisville, 2009

A Thesis Approved on

November 7, 2012

By the following Thesis Committee:

J. Blaine Hudson, Thesis Chair

Tomarra Adams

Amy Hirschy 


\section{DEDICATION}

\section{This thesis is dedicated to my parents}

Revs. O. Lacy and Brenda Evans

for their prayers and support throughout this journey of life.

Also to Dr. Tomarra Adams for the legacy of excellence

you continue to demonstrate; not only for me but for so many others. 


\section{ACKNOWLEDGMENTS}

I owe my deepest gratitude to my advisor, Dr. Tomarra A. Adams, for her guidance, patience, wisdom, support, and sisterhood. You exemplify the very essence of a true mentor, for that I honor you. I would also like to acknowledge my other committee members, Dr. J. Blaine Hudson and Dr. Amy Hirschy for not only your support but also your continuous display of passion for and in the field of education. I would also like to acknowledge the faculty and staff of the Pan-African Studies Department for your support, especially from Dr. Theresa Rajack-Talley, Dr. Tommy Parker, and Professor LaTonia Craig. I would like to acknowledge my cohort, Scholars Brandon Pittman, Patrice Ferguson and Tamara Spiller, it has been an interesting journey, and I wish you all the best. To Mr. Omar Shareef Price, my only cohort completing a thesis with me, for your support and friendship I am forever grateful.

I gratefully thank Mrs. Cynthia Revels-Young for her words of encouragement throughout this process. I am thankful that in the midst of your $\mathrm{PhD}$ dissertation, you were always there to offer a genuine smile and warm embrace.

I would like to acknowledge and thank my AMEZ Church family as well as my extended family across the US for their encouragement, prayers, and various gestures of love. Lastly, I must acknowledge my family; Ma, Dad, Jason, and Justin (Candice). Thank you for supporting me throughout my studies at the University of Louisville. Ma, thanks for understanding that sleepovers in the office were sometimes necessary. I love you all. 


\begin{abstract}
COMBATING THE SOPHOMORE SLUMP THROUGH PEER-MENTORING AMONG AFRICAN AMERICAN STUDENTS AT PREDOMINATELY WHITE INSTITUTIONS

Tiffany C. Evans

November 7, 2011

There is a plethora of research regarding the first year undergraduate student experience; however, 2nd year students are facing adversity and consequently high rates of attrition. This phenomenon is known as the sophomore slump. There is limited research of how the sophomore slump impacts African Americans and research supports involvement, particularly as a peer mentor, increases student persistence beyond the 2 nd year. This study uses Tinto's theory of student departure and Collin's theory of othermothering to explore how the academic and social skills of CONECT peer mentors contribute to their experiences as peer mentors and their overall persistence.
\end{abstract}




\section{TABLE OF CONTENTS}

\section{PAGE}

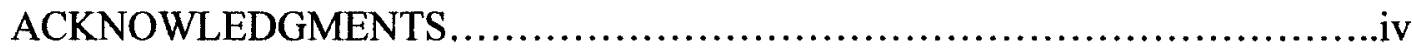

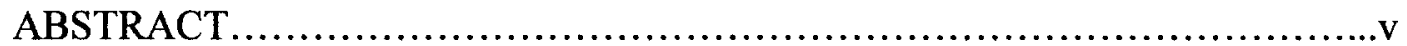

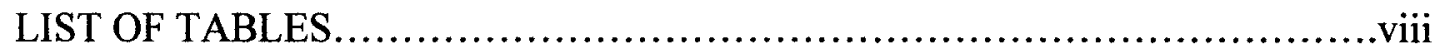

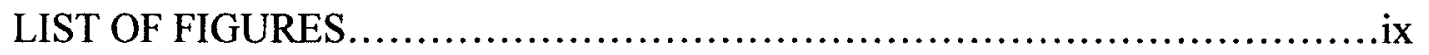

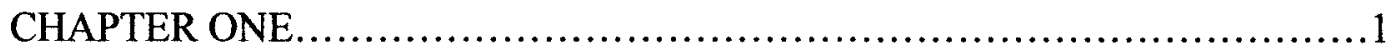

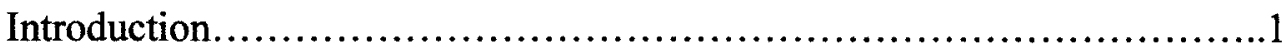

Literature Review...................................................

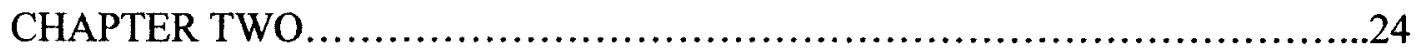

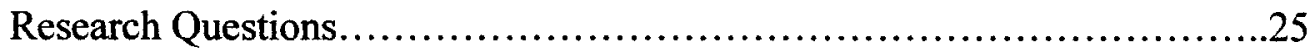

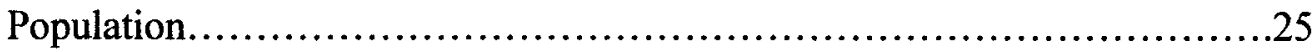

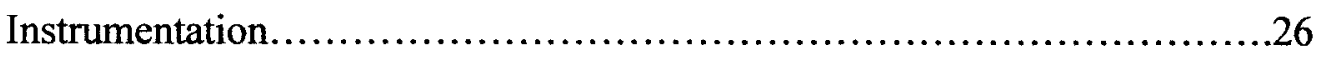

Procedures for Collection of Data.......................................27

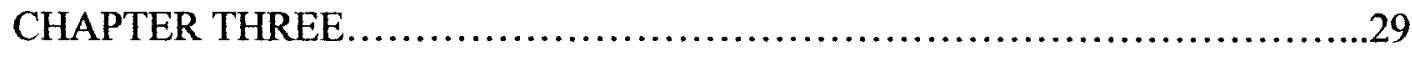

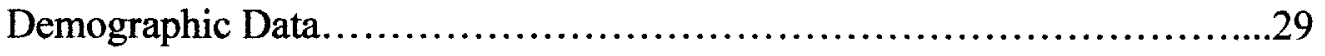

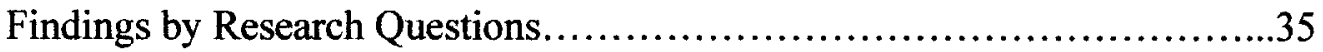

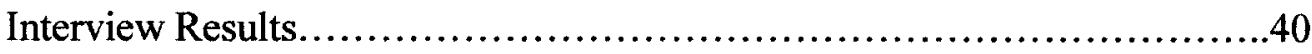

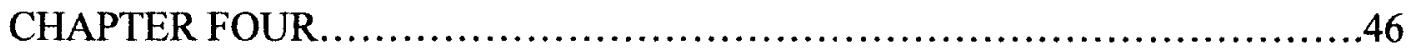

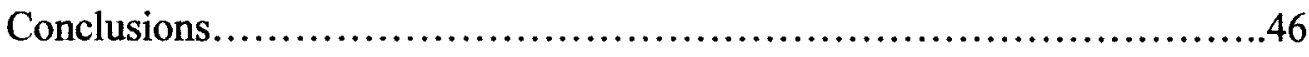

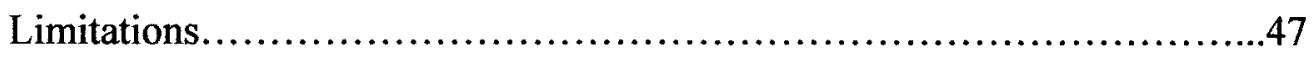

Recommendations for Higher Education...............................48 
REFERENCES.........................................................50

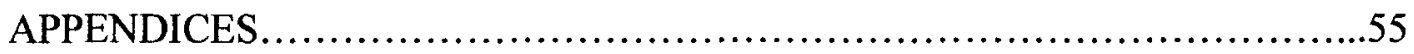

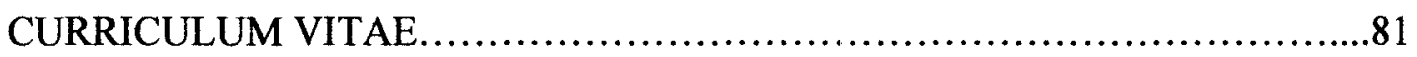




\section{LIST OF TABLES}

TABLE

PAGE

1. Institutional initiatives toward sophomores................................18

2. Frequencies and percentage of years of enrollment.............................30

3. Frequencies and percentage of high school GPA ..............................30

4. Frequencies and percentage of involvement and classification..................31

5. Frequencies and percentage for scholarship renewal..........................31

6. Frequencies and percentages for parental income............................32

7. Frequencies of rank of university's choice ...................................32

8. Frequencies of mentors' highest expected academic degree.....................33

9. Frequencies and percentages for mothers' education..........................34

10. Frequencies and percentages for fathers' education............................34

11. Frequencies and percentages of level of importance of graduation.................35

12. Correlation of mentoring status and integration.................................. 


\section{LIST OF FIGURES}

$\begin{array}{ll}\text { FIGURE PAGE } & \text { PAR }\end{array}$

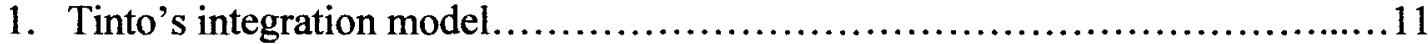

2. Conceptual model of student departure.................................... 12 


\section{CHAPTER ONE}

Introduction and Literature Review

Within the United States, institutions of higher education have placed a great deal of focus on the retention and persistence of their students. A large sum of money and other resources have been invested to creating support programs and services, especially for first year students. However, 2nd year students are facing adversity, and consequently, high rates of attrition. This phenomenon is known as the sophomore slump. There is limited research of how the sophomore slump impacts African Americans. This may be attributed to their under-representation on campus and issues of climate at Predominately White Institutions (PWIs). Research supports involvement, particularly as a peer mentor, increases student persistence beyond the 2 nd year. Therefore, examining the relationship between students' level of involvement during their sophomore year and their ability to develop the skills often cited to promote their success is essential in the continued research on African American student retention and graduation. This study will use Tinto's theory $(1975,1987,1994)$ of student departure and Collin's theory (2000) of other-mothering to explore how the academic and social skills of CONECT peer mentors at the University of Louisville contribute to their experiences as peer mentors and their persistence.

The following section provides a review of literature that contains an overview of models of retention in higher education, followed by the discussion of social and 
academic adjustment and integration of African Americans students at PWIs. This chapter will also present an overview of the sophomore slump phenomenon and initiatives put in place to combat symptoms of the slump with great emphasis on peer mentoring.

\section{Literature Review}

In today's society, education is a key to success in our ever-evolving world. The economic recession as well as its recovery process has demonstrated the importance of educational attainment. In 2004, the U.S. Census Bureau's Educational Attainment Report notes $28 \%$ of Americans have a college degree, an all-time high. As time passes, the attainment of a degree will only strengthen the ability to qualify for a flourishing career. Therefore, the retention and persistence of students in higher education has risen to the forefront of state legislation, higher education institutions, and research initiatives. In the early 1990 s, roughly $50 \%$ of college dropouts occur during the first year of college, while $35 \%$ of dropouts occur during their second year of college (Wilder, 1993). In 2006, $42 \%$ of African American high school graduates enrolled in higher education; however, only $19.5 \%$ of African Americans over the age of 25 have a bachelor's degree (Vital Signs, 2008). Such statistics continue to stimulate the demand of research concerning retention and persistence, especially that of first and second-year students. As a result of this research, student support services and programs have been created or enhanced in order to meet the needs of these students. Despite their improvements, national graduation rates remain stagnate. The success during the first year of school does not translate to the second year where students are encountering a distinct set of problems. As 
a result of those problems and their inability to address them, second-year students are consistently departing from college at an alarming rate.

\section{Parameters of Peresistence and Retention}

The study of retention and student persistence has been a concern throughout the history of education. As previously noted, there is an increasing importance of educational attainment with the downward state of the U.S. economy and the increased numbers of retirement within the baby boomer generation. There is an increasing need to have an experienced or educated workforce in the near future, accentuating the gaps in student enrollment and graduation.

Student retention is directly linked to student persistence, and these words are often used interchangeably. Institutions differentiate the terms by using "retention" as an institutional measure and "persistence" as a student measure. Therefore, institutions retain while students persist (Hudson, 2010; Adams, 2004). Retention is based on the institution's ability to ensure the return of a student until their time of graduation. Student persistence acknowledges the skills and abilities students master within and outside of the classroom that support their ability to be successful at the college level. Students' persistence also increases their accessibility to financial opportunity in the job market. Bean (1990) further discussed this financial impact of persistence and stated: "For individuals, departure from college before graduating can represent a personal failure to achieve educational objectives, an income about 15 percent below that of contemporaries who graduate from college, and the opportunity cost of an investment that will yield little financial benefit" (p. 170). In 2008, the median annual earnings of bachelor degree holders was $\$ 50,000$ compared to $\$ 28,500$ which is earned by high 
school diploma holders (National Center for Education Statistics, 2010). The employability of its residence is of considerable concern for state government officials, and as Bean insinuates, there is a relationship between rate of employment, earnings, and college completion. Therefore, there is a need to invest, much more intentionally, in what happens with students in college as well as college preparation.

Retention is also important for instutions of higher education for polititcal and economic reasons. Slaughter and Lesilie (1997) discuss the impact of academic capitalism and how the industrial revolution at the end of the $19^{\text {th }}$ century generated the wealth for the postsecondary education as well as the progressionalization of society, while the globalization of the political economy has destabilized the patterns of university professional work in the $21^{\text {st }}$ century. Ultimately, regardless of the variety of mission statements, all educational institutions are fundamentally designed to educate students in hopes of molding them into productive citizens who enrich society. Colleges and universities are expected to generate revenue, now mostly based on student tutition. Previously, institutions received the majority of its funding from external financial supports via private benefactors (i.e. alumni, community figures, etc.) and state government (U.S. Dept. of Education, politicians, etc.). Since there has been an increased shift in the source of funding from the state to the institution, it has also begun to alter the way that institutions design its curriculum, allocate faculty workloads, offer student services, and engage the cost of tuition (Slaughter \& Leslie, 1997.) A high rate of attrition is not only a fiscal problem for schools, but also a symbolic failure of an institution to achieve its mission. There are definite incentives and rewards for some aspects of academic careers to engage academic capitalism, there are also constraints and 
disincentives for others (Slaughter \& Leslie, 1997). One of those disincentives is the direct impact it has on students.

\section{Sophomore Slump}

In 2000, Schreiner and Pattengale grasped the attention of educational researchers with their monograph, Visible solutions for invisible students: Helping sophomores succeed. Administrators and researchers struggle to understand the second-year experience. Although there is more information available now than 10 years ago, a great deal of the research available is qualitative which doesn't allow for opportunities to generalize its findings. Therefore, research seeks to establish a solid understanding of the second-year experience and a more comprehensive way to intervene. As the research grows to describe the general student populations, there is even less research available regarding intersection of racial identity development, academic and social integration during the second-year experience.

Despite the research made available regarding the second-year student experience, there is not a concrete definition of the slump. Within higher education the "sophomore slump" is used to describe and encompass the difficulties second-year students experience while at their respective institution of higher education. Difficulty is experienced at each level of matriculation within education; however, the second year of study has proven to offer a profusion of challenges. During this period, students struggle through developmental processes that include some level of satisfaction with their decisions about their personal and academic lives (Feldman \& Newcomb, 1969). Although, there are several variables that influence this dissatisfaction. Tobolowsky and Serven (2007) expounds upon the phenomenon by describing the slump to be "a time in 
which students struggle to establish themselves as individuals, find the passions and develop a personal worldview, determine what they want to get out of college, and establish short and long-term goals (ix-x)." It is during this period that is becomes more imperative for students to have a sense of self and/or a strong support system to guide them through the educational process. If this is lacking, it increases the likelihood they may encounter issues that lead to stop-out or dropout.

Sophomore slump is considered a phenomenon; however, Freedman (1956) emphasized that student departure during the second year is a result of a period of uncertainty for the students. He highlighted how sophomores experience a great deal of pressure, both intrinsically and extrinsically; these students struggle with their capabilities, selection of an academic major, motivational issues, and establishing their identity separate from their parents, friends and past mentors. As a result of their confusion, they become stressed, overwhelmed, depressed and unable to perform within an academic setting; therefore, they depart.

This time of confusion is also a result of whether or not students have established an identity within the institution. Miller (2006) discusses the freshness of the first-year experience and how, as any relationship does, that newness wears off. He states students are able to identify those little things they never noticed before and become less enchanted with the institution. Traditionally, institutions have overlooked second-year students as a consequence of their emphasis on first-year students and securing the success of graduating seniors. Though some second-year students may feel they have a little more experience, the reality is that they are still in a crucial stage of development. Flanagan (1991) describes the second-year "to be a time when students find they cannot 
obtain the courses, housing, financial aid, or type of academic advising and institutional attention they may have received as freshmen" (p.5). If students do not connect with a network or plug in to meaningful extracurricular activities, outside of the classroom, establish some specific academic goals, emerge from that "freshman fifteen" with some balance on personal health and wellness, they may find themselves facing the sophomore slump sooner than they think. Without intentional outreach and support from the institution, a sense of neglect can be devastating in their transition and damage the psyche of the student.

Since Freedman's findings of the adversity facing sophomores, more current research has shown that second-year students experience the highest expectations, academically and socially (Pattengale \& Schreiner, 2000). Upcraft, Gardner, and Barefoot (2005) outlined and promoted a series of developmental tasks for advisors to address with first-year students that can easily be adapted to further counter issues related to the sophomore slump based on Miller's research. These developmental tasks included: a) developing intellectual and academic competence; b) establishing and maintaining interpersonal relationships; c) exploring identity development; d) deciding on a career; e) maintaining health and wellness; f) considering faith and the spiritual dimensions of life; g) developing multicultural awareness, and h) developing civic responsibility. These attributes are necessary to encompass a holistic lifestyle; however, it is an ambitious notion especially for first-year students. Grasping an understanding of all those aspects extends beyond the first year and have been cited to counter the sophomore slump.

Schaller (2005) conducted a qualitative study seeking to understand how engaged sophomore students interpreted their sophomore year experience. As a result of her study, 
she was able to develop four stages, which illustrates the journey sophomores encounter. The model includes: a) random exploration; b) focus exploration; c) tentative choices, and d) commitment. Random exploration describes the initial exposure to the college experience in regards to relationships and academic settings. During this time of random exploration, she states students avoid making direct and intentional decisions. Schaller describes the decision-making process to be very "haphazard." This stage begins during the first year and sometimes continues into the beginning of the second year.

Students then enter the focused exploration stage. During this stage, second-year students are expected to make decisions that concern their major, identity, and relationships. These decisions are not concrete either, however, it requires a well thought out deliberation. Schaller (2005) explains that too much time in this stage may lead to dissatisfaction and anxiety as a result of the pressure caused by indecision. It is not until students become more active and engaged that they are able to fully emerge to the next stage of tentative choices.

During the tentative choices stage, students are making choices about their academics, personal relationships and personal values. It is during this stage where students begin to consider themselves as mature and responsible individuals. Lastly, the commitment stage is characterized by concrete decisions. If students enter into the commitment stage without being secure in their beliefs and decisions, they are likely to re-examine their decisions regarding their major, relationships and dropout. This introduces opportunity for institutional intervention. It is during these developmental and decision-making phases that students require intentional application of services to begin 
to counter the impact of the sophomore slump and further integrate students into the college environment.

Tinto's Integration Model not only addresses the institution's commitment to the student body, but also the student's individual commitment to their academic success. However, the varied attributes identified in the successful first-year students are the same attributes that are shown to be stumbling blocks in the sophomore year. During the first year, students are motivated by support provided by advising, professors and the institution as a whole. Second-year students need academic advising and advising which places emphasis on career and academic planning and co-curricular participation to help with their lack of motivation in their performance and persistence (Schreiner, 2000). Koring (2005) stated that advisors must personalize the transition for students in their academic planning and better identify the resources they access most often for referral.

\section{Models of Retention}

Spady $(1970,1971)$ proposed a correlation between student attrition and Durkheim's (1951) theory on the relationship between social factors and suicide. Spady's $(1970,1971)$ work served as the foundation for Tinto's model on students' departure from institutions of higher education. In Tinto's $(1975,1987,1993)$ expansion of Spady's study to address specific variables involved in student departure, he developed a grand theory for student retention. Tinto's Integration Model suggested that retention is related to students' abilities and actions to become an involved actor in their institution (Tinto, 1987). The Integration Model suggests the need for a complement between the institutional environment and student commitment. 'Tinto's theory (1987) suggests that stimulation and encouragement from faculty and students, e.g. peer groups and 
involvement with extracurricular activities, correlate with persistence. A positive relationship will lead to higher student integration within academic and social domains of college life, and thus yield a greater probability of persistence.

The purpose of Durkheim's study was to use sociological principles to explain why suicide rates varied from country to country. He examined peoples' social and intellectual attributes within the context of their social environment. Within the theory he discussed four types of suicide: altruistic, anomic, fatalistic and egotistical. Altruistic suicide is morally acceptable; e.g. Japanese kamikaze suicide bombings during World War II. It was considered an honor to die in the name of their country. Anomic suicide occurs when a person encounters a 'temporary disruption of normal conditions [in] society which results in the breakdown of the social and intellectual bond to society' (Tinto, 1987). Anomic suicide derives from a sudden state of normalessness; where persons lose hold of their ability to make sound decisions and tend to isolate themselves. As a result of personal turmoil, the individual becomes morally conflicted and retreats from any social support. Fatalistic suicide is the third type discussed. Fatalistic suicide is the complete opposite of anomic suicide; it is the result of the constant and perpetual feeling of hopelessness and suicide is the only option. Fatalistic suicide is often a result of living in an oppressive society. Therefore, the feeling of hopelessness is not an abrupt occurrence; fatalistic suicide is a result of long-standing social and intellectual disruption. The final type of suicide discussed is egotistical. This form of suicide occurs when a member of society attempts to integrate and establish themselves within the larger group and is unsuccessful. Durkheim believed that integration came in two forms: social and intellectual. Intellectual integration would consist of sharing values with the society; 
avoiding deviance. Social integration would consist of obtaining affiliation within society on a day-to-day basis; social acceptance.

Tinto's Integration Model continues to serve as the grand theory for retention in higher education. Tinto (1975) and Spady (1971) focused their research around the concept of egotistical suicide as a foundation. Tinto's 1987 theory focuses on the interconnectedness of three fundamental variables: student's background (prior educational experiences, family attributes, and individual attributes), commitment to goal of graduation and commitment to the institution of higher education. Tinto directly links the student's attributes to their commitment to college graduation and to the institution as illustrated in Figure 1.

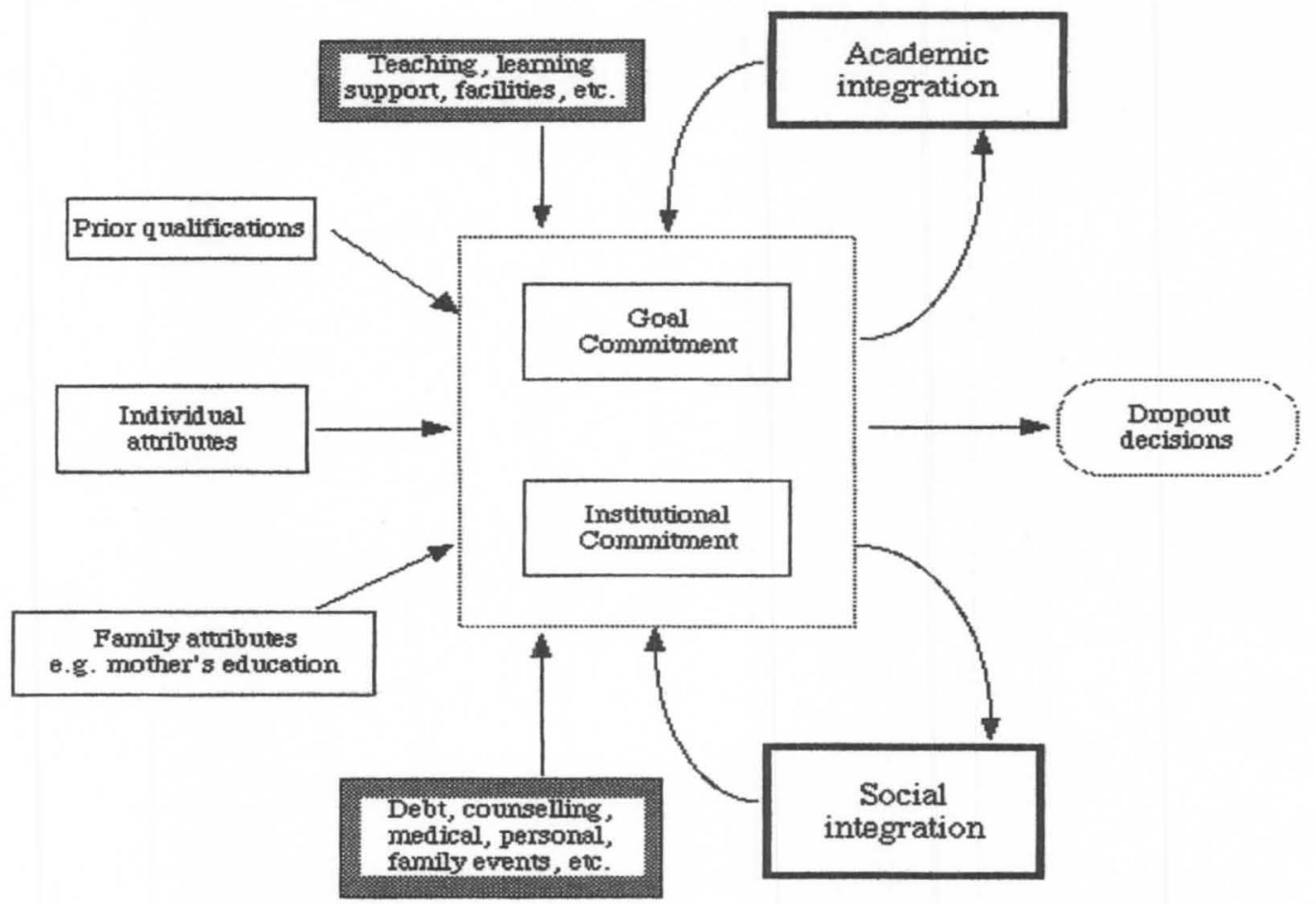

The initial commitment to graduation and to the institution is based on their background; pre-college attributes. However, students' experiences within academic and social settings, whether formal or informal, shape their subsequent commitment to 
college graduation and to the institution. Successful academic integration is the result of the students and institutions having shared values in regards to academics. Successful social integration is the result of establishing meaningful relationships with peers at school as well as faculty. Tinto later revised his model (as illustrated in Figure 2) after conducting a longitudinal study (1994) that allowed Tinto to place greater emphasis on the importance of the institution's commitment (both socially and academically) to the prediction of student retention. Within Tinto's latter model, he highlights the student should reach a point of separation from their pre-college attributes; into a reflection of the institution's values and deportment.

Figure 2. Conceptual model of student departure model (Tinto, 1994)

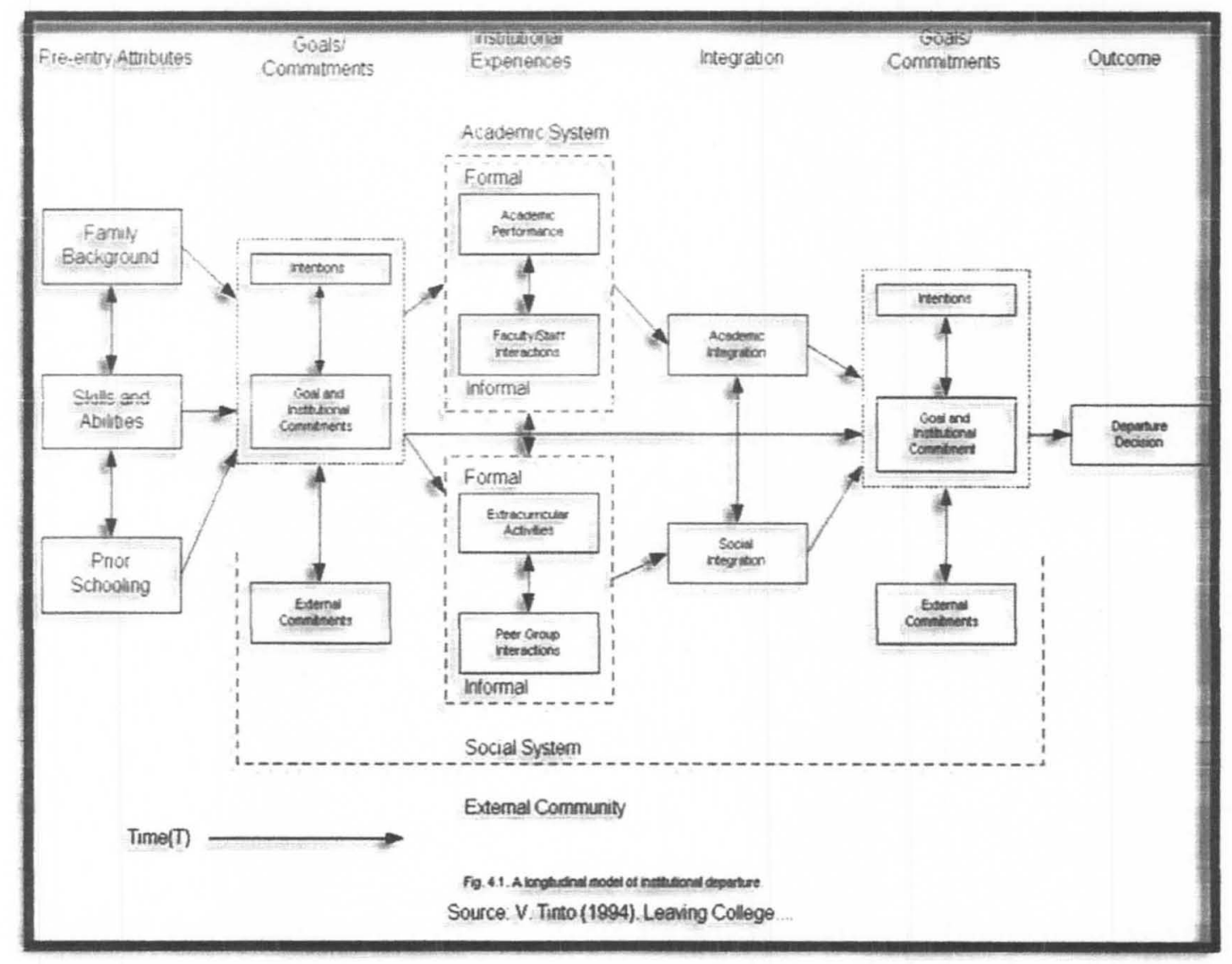

Tinto's model took into consideration "pre-college" attributes that include family 
background, previous educational experiences, and individual abilities. These factors are critical when examining the African American student experience due to the strong communal ties within the African American population. These "pre-college" attributes greatly impact students' motivation, self-efficacy

\section{Social Integration of African American College Students in Higher Education}

Although, first-year students have a great deal of change to endure during their transition into the college life, the commitment to continue their college education in their second year requires another transitional point for students and a need for a greater level of support. The social integration of students is considered to be a key factor when making the transition to college. Gerdes and Mallinckrodt (1994) conducted a longitudinal study on retention in order to find the relevance of social integration and its relationship to students' retention. This study was conducted with the use of the Student Adaptation to College Questionaire (SACQ), a 67 question instrument examining academic adjustment, social adjustment, personal, and institutional adjustments. Students were asked to complete the survey upon entry into their first year and then again six years after their enollement. The results suggested informal interaction with faculty, satistifaction with courses, and confidence in self were indicators of persistence for academically successful students. Additionally, satistifaction with extracurricular activities was the indicator of retention for students who struggle academically. Although Gerdes and Mallinckrodt's study did not indicate the impact of race on social integration, Allen (1982) and Schwitzer (1999) focused directly on the social integration of African American students. 
African-Americans come from a history built on a sense of collectiveness and community. That factor should not to be excluded when examining their success in higher education; especially at PWIs. It is essential for African American students to feel a part of a community in order to accomplish their social and academic goals. AfricanAmerican students who attend PWIs do not often feel as though they belong on campus (Allen, 1992; Bradley, 1967; Madrazo-Peterson \& Rodriquez, 1978) and consider the atmosphere to be hostile and unsupportive (Saddlemire, 1996; Wilson, 1997). Students who are given positive attention and feedback from peers, faculty, staff, and adminstrators have the tendency to achieve at the college level (Davis, 1991). Accordingly, Allen (1982) and Schwitzer (1999) suggest that positive relationships with faculty, positive racial climate, and support networks within the African American community were crucial elements in successful social integration.

African-American students are more likely than Causasian students to perceive the college environment as unwelcoming and hostile (Flowers 2003; Ancis, Sedlacek, and Morh, 2000). Heyward (1985) concluded that African-American students do not look to Caucasian faculty and staff as role models for their leadership (Sedlacek, 1987). Fleming (1984) and Cokley (2003) highlight the importance of African-American students at PWIs having positive reinforcement from African American faculty/staff/administrators. When supportive they are not available, African American students create their own culturally homogenous networks (Kenny \& Perez, 1996). These networks can range from culturally specific groups to sororities and fraternities. Sometimes those social networks can have requirements based on accumulation of credit hours or previous extracurricular involvement. It is through these various experiences that 
students begin to forge an identity that defines how they will academically engage at the institution. This academic integration marks another way students integrate into college.

\section{Academic Integration}

There have been a host of research studies on the presence and success of African American students in higher education, especially at PWIs, in order to increase their retention rate. Successful academic integration is based on academic skills and motivation (Gerdes \& Mallinckrodt, 1994). Admittedly, much of the focus of this study relates to non-cognitive variables, yet there must be some discussion on how cognition impacts student persistence in the sophomore year. In 2003, Flowers and Pascarella conducted a longitudinal study of African American and Caucasian students from 18 different four-year institutions in order to examine the cognitive effects of race in college. Their empirical/quantitative research used pre-college and background traits, institutional characteristics, and academic and social experiences as variables. Flowers and Pascarella (2003) found that Caucasian students make significantly higher cognitive advancements in college in comparison to the first three years for African-American students. Unless there is an adoption of the genetic inferiority proposed by researchers like Herrnstein and Murray (1994) who conclude a diminished intellectual capacity for African-Americans to perform at the same level of their White counterparts, it may be attributed to climate of the campus. African Americans are more likely to become academically isolated in comparison to Caucasian or Asian students (Maron et al, 2000). This academic isolation is often a result of previous educational background experiences, such as high school GPA or SAT/ACT scores. According to Schwitzer and Thomas (1998), a majority of African American students transition into college with a sense of under-preparedness 
academically. A combination of a hostile campus climate, the sense of underpreparedness, and the traditional issues faced in transitioning into a new setting can be overwhelming. Though there are developmental services created to aid this feeling, African Americans often consider those resources to be nonproductive and unwelcoming as well.

Within the classroom setting, African American students describe the overwhelming pressure to actively engage in discussion and activities due to the idea that Caucasian students expected them to represent and reinforce images associated with their race. Fordham and Ogbu (1986) noted that low academic achievement among African American students is a result of their culture contradictory to mainstream US society. As a result, African American students adopt the idea of racelessness (Fordham, 1988, 1996) in order to cope within the classroom/campus environment. African American students believe they are forced to choose between reinforcing negative connotations associated with being black (i.e. use of Ebonics, slang, etc) or losing legitimacy within the black community and risk being labeled "white" or "sellout". Therefore, high-achieving African American students believe distancing themselves from the African American community is the only way to thrive. Adams (2005) found that when students interact more with African American faculty, the more important they felt it was to connect with other students of the same race and stand up against the majority population or oppression. This speaks to a level of racial identity development where students were able to counter some stereotypes about their cognitive abilities without feeling they also had to abandon their race. The motivation for student engagement and achievement was further reinforced by the content of courses related to African American issues. "African 
American females racial identity had a positive and significant correlation with intrinsic motivation while African American males racial identity had a negative and nonsignificant correlation with intrinsic motivation" (Cokley, 2003, p.527). What this means is, as African Americans are faced with challenges related to race, African American women are more likely to have the motivational fortitude to progress through the identified goals and decisions made to aid in their success. Cokley (2003) establishes the importance of the locus of control and its relationships with African American students potential for academic success.

Graham (1997) critiques three assumptions about African-Americans: a) AfricanAmericans lack personality traits associated with achievement motivation because of the lack of opportunity to be adequately socialized for achievement-related behavior, which he refuted because of the lack of empirical evidence; b) African-Americans are less likely to believe in internal or personal control of outcomes, which he suggested was inconclusive; c) poor academic achievement and economic disadvantage have led African Americans to hold negative views of themselves and to develop low expectations for the future. Graham provides evidence that shows that African American students maintain high levels of self-concept of their ability and high expectations of future success regardless of disadvantages. This is known as attribution theory. Attribution theory provides a framework for understanding causal attributions given to explain why certain outcomes occur. Causal attribution are used to answer such questions as "Why did I receive a low or high grade?" When searching causation, after a positive or negative experience, students may ask themselves whether or not it was related to their ability or effort, which are the more commonly perceived reasons for a give outcome. When 
examing why students fall subject to the sophomore slump, it may be a relationship between how they are motivated. Once these various variables are engaged, it becomes a much more complex question of how the sophomore slump impacts African American students and how this is being tracked and addressed.

Schreiner (2010) suggest institutions provide second-year students with academic challenges and personal support during this developmental stage by: a) connecting students to faculty and engaging them in the learning process; b) focusing sophomore advising that connects present and future identities; c) building purpose and peer satisfaction through selective campus involvement; d) empowering students to navigate the institution's systems; and e) helping sophomores connect their strengths to academic success. The National Resource Center for the First-Year Experience and Students in Transitions has cataloged various programs and initiatives developed by private and public institutions, which specifically targets second year students. Table 3 provides an outline of programs/initiatives designed to address Schreiner's suggestion of challenges and support when aiding the academic and social integration of second-year students.

Table 1: Institutional Initiatives Specifically or Intentionally Geared Toward Sophomores (Tobolowsky \& Serven, 2007)

\begin{tabular}{|l|r|r|}
\hline Initiative Type & \multicolumn{1}{l|}{ Number } & \multicolumn{1}{l|}{ Percentage } \\
\hline At least one sophomore year initiative $(\mathrm{n}=382)$ & 128 & $33.5 \%$ \\
\hline & 89 & 74.2 \\
\hline Career Planning & 79 & 65.3 \\
\hline Programs to assist with selection of major & 75 & 61 \\
\hline Academic Advising & 56 & 46.3 \\
\hline Class events (e.g., trips, dinners, dances) & 54 & 46.2 \\
\hline Peer mentoring by sophomores & 46 & 38.7 \\
\hline Student government (e.g. sophomore council) & 40 & 33.6 \\
\hline Residence life (e.g. sophomore -specific living arrangements & 38 & 32.8 \\
\hline Community service / service-learning & 37 & 31.4 \\
\hline Faculty and staff mentors for sophomore students & & \\
\hline
\end{tabular}




\begin{tabular}{|l|r|r|}
\hline Credit-bearing course (e.g. sophomore seminar) & 24 & 21.1 \\
\hline Opportunities to co-teach or assist in teaching a class & 24 & 20.7 \\
\hline Financial Aid (e.g. sophomore scholarships, loans) & 23 & 19.3 \\
\hline Cultural enrichment (i.e. plays, musical events, multicultural fairs) & 22 & 18.8 \\
\hline Curricular learning communities (i.e. linked courses) & 20 & 17.7 \\
\hline Publications for sophomores (e.g. sophomore newsletter or website) & 20 & 16.8 \\
\hline Peer mentoring for sophomores (i.e., student mentoring) & 18 & 15.4 \\
\hline Other initiatives (n-77) & 22 & 28.6 \\
\hline
\end{tabular}

Note. N's for each initiative type ranged from 113 to 123 (of the 128 institutions with at least one initiative). Percentages reported are calculated from the $\mathrm{N}$ for each specific item (Tobolowsky \& Serven, 2007).

Though there is limited research available regarding the phenomenon described as the sophomore slump, and even less addressing its relationship with race, literature suggests that peer mentoring (with sophomores as the mentors) play a key role in engaging students while providing them with guidance; thereby employing Schreiner's idea of challenge and support. It would also be beneficial to explore the experiences of African American peer mentors at PWI and their attitude towards their role at their institution.

\section{Mentoring}

Every year, institutions of higher education dedicate thousands of dollars in order to attract new students to their institution; however, great emphasis and resources are being placed upon keeping the students enrolled through student services that builds students' skills and assist with their adjustment to college. Pascarella and Terenzini (1991) concluded that there is a positive relationship between student persistence and the amount of non-classroom time and interaction, which translate into true social integration. Over the past two decades, peer mentoring has emerged as a vital student support service (Rodger \& Tremblay, 2003). As a result, formal mentoring programs were implemented and financially supported by institutions throughout the United States 
to address retention. However, with increasing demands on faculty and expanding faculty-student ratios, it is difficult to establish faculty mentor programs. Peer mentoring addresses the developmental needs of students while alleviating faculty load.

Peer mentoring benefits both students and institutions because it demonstrates the commitment to establishing supportive communities and encourages integration (Braxton $\&$ Mundy, 2002). Peer relationships provide emotional and social support during adjustments to college life by sharing their experiences through direct involvement, peer mentoring is a crucial instrument in reaching out and supporting students (Austin, 1996). Mentors model specific ways to adjust to campus. Students' feelings toward continuing school is strongly associated with ties to social integration; therefore, students who do not establish a personal connection are more likely to be lost to attrition (Tinto, 1975, Harmon, 2006). Effective peer mentors are able to support students academically and psychosocially (Tierney, Baldwin-Grossman, \& Resch, 2000), which is crucial when addressing the need for a sense of community for African American students at PWIs. African American students at PWIs experience difficulties developing positive relationships with White faculty and even their White counterparts. As a result, African American students are more apt to look to family, friends, or academic counselors who are minorities rather than White faculty (Guiffrida, 2003, 2004, 2005). Although there are conflicting findings, Fischer (2007) reports maintaining connections off campus has a negative effects on grades for African Americans; therefore, positive relationships must be established on campus in order to promote their retention. Although some findings report African American students at PWIs have higher levels of contact with faculty than White students, it has also shown they are less satisfied with the overall institution 
(Eimers \& Pike, 1996). African American students desire a genuine relationship outside of the classroom.

\section{Responsibilities of Mentors}

Being a mentor is a special and trusting role in which one person, the more knowing, is in a position to assist another person, the less knowing. Being a mentor carries a commitment of time and attention to a person who wants to make improvements in their life. As a mentor, you will have a variety of ways in which you will encounter your partner (the person you are mentoring). These may include offering suggestions, modeling behavior, providing support, and even making gentle challenges that will nudge the person to make necessary changes. It should be carefully noted that in forming a mentoring relationship, the basis is not to create dependency but to promote self-responsibility, not to decide for someone, but to encourage self-direction. A mentor may serve as a catalyst for change (Ender \& Newton, 2000, p.16-17).

The extensive use of peer mentoring across higher education addresses a large spectrum of issues including registering for classes, selecting a major, getting involved with student organizations on campus, and managing roommates. African Americans require a deeper sense of mentoring based on the willingness to do what is necessary to address issues that impede their decision-making process or compromise their motivation. Mentoring African American students goes beyond some of the traditional definitions of mentoring as its focus is not limited to academic issues. Since there are layered psychosocial issues that interfere with the sophomore experience and the constant barriers African American students face when entering college, effective mentoring becomes more like extended family. This sense of mentoring is encompassed within the concept of other-mothering.

\section{The concept of 'other-mothering'}

Personal interactions with faculty/staff/administrators play a major role in the success of African American students. When they mentor African American students and 
communicate extensive dedication through individual time commitment, expressed concern and open, it is characterized as "other-mothering." The concept of othermothering originates during slavery within the United States and is described as "women who assist blood-mothers by sharing mothering responsibilities" (Collins, 2000, p. 178). Mothering others' children within slave communities was necessary due to women's (mothers') workload, being sold away (either mother or child) or death. Similar dynamics exist for African American students at PWIs, in the sense that they are isolated from their families of origin, attempting to be successful in hostile environments, and working to overcome deficits from their secondary educational experiences.

The concept of 'other-mothering' is also linked to education. African Americans slaves were not able to be educated; therefore, women begun to educate and care for children outside of primary needs (Dubey, 1995). The practice of other-mothering allowed Black women to educate and socialize children in their culture and traditions in order to uplift the Black community and assist them in resisting White domination (Guiffrida, 2005). The practice of other-mothering extends beyond slavery and is practiced within the formal education system by African American faculty. Faculty who practices other-mothering rise above and beyond their responsibilities to provide students with the support they need to be successful. Going beyond their responsibilities are characterized by focusing on the holistic student while providing them with challenges and support.

\section{The C.O.N.E.C.T. Peer Mentor Program}

In hopes to address social and academic issues facing African American first-year students, the College of Arts and Sciences created the Caring Of New students 
Experiencing College Transition (C.O.N.E.C.T.) Peer Mentor Program. The

C.O.N.E.C.T. Program operates as an intrusive peer mentoring program (Correll, 2005) whose purpose is to increase the retention and graduation rates among first-year African American students. Majority of the students enrolled in the program, as is true for the incoming freshman class at the University of Louisville, are recipients of the Woodford R. Porter Scholarship, a scholarship awarded to African American high school seniors to demonstrate excellence in academics, community involvement and leadership. The program pairs first-year African-American students with an upper classmen who customizes a relationship to meet the needs of the freshman that include counseling and awareness of how to access resources available on campus like tutoring, networking, promotion of cultural events, workshops, how to maximize financial aid and scholarships on campus.

The program employs approximately 20 paid peer mentors each academic year. Each mentor is responsible for 12-20 mentees. In preparation to serve, mentors are also trained regarding self-reflection, leadership skills, campus resources, and community involvement. The C.O.N.E.C.T. Program has been in existence since 2007, addressing the academic and social integration needs of first year African American students. While promoting the persistence of first year students, the program has also promoted the persistence of its mentors; providing them with personal relationships with trained advisors, leadership skills, established relationships within the community through community service and a safe communal environment that allows them to explore and express themselves freely. 


\section{CHAPTER TWO}

\section{Research Methodology}

The future of the U.S economy is held in the hands of students in higher education. The retention and graduation of the college student population continues to challenge intuitions. Consequently, institutions and researchers have placed retention at the forefront of their agendas, especially concerning the minority populations (African American, Asian, and Hispanic). This chapter addresses the methodological procedures used to address the research questions outlined in Chapter 1. That is, what is the relationship between the sophomore slump, academic and social integration, and persistence of African American mentors? This answer to this question is central to this study.

In order to examine the retention of African American peer mentors who persist beyond their freshmen year using social and academic integration scale factors that examines the experiences of peer mentors and academic persistence and ability to combat symptoms of the sophomore slump. This research will use Dr. Vincent Tinto's theory of student departure (1993) and Dr. Patricia Hill Collins' theory of 'other-mothering' as the primary theoretical framework. An online survey was used based on the Institutional Integration Scale Survey (1980) by Pascarella and Terenzini (Appendix A) and approved by the Institutional Research Board (IRB) at the University of Louisville. The target question is: does serving as an African American peer mentor assist in establishing 
students to integrate socially and academically at PWIs while they persist beyond their first year. To better prepare to respond to the research question, subsets of it have been established.

\section{Research Questions}

RQ1: What is the relationship between being a peer mentor and academic success during the second year experience?

1a. What are the cumulative GPA during $2^{\text {nd }}$ and $3^{\text {rd }}$ year of those serving as peer mentors?

RQ2: What is the relationship between social integration of $2^{\text {nd }}$ year students in the C.O.N.E.C.T. Mentor Program with their academic integration?

\section{Population}

The population in this study consisted of sixteen college students (sophomores, juniors, and seniors) who attended the University of Louisville. Ten of the participants served as peer mentors in the C.O.N.E.C.T. Peer Mentor Program between 2009-2011 academic years. The remaining six participants were students of the University of Louisville, who have never served as mentors. Of the sixteen participants, all were African American females. There were four sophomores, eight juniors, and four seniors; two sophomores, six juniors, and two seniors served as peer mentors.

\section{Description of the University}

In this study, the University of Louisville (UofL), a public predominately white institution, serves as the primary focus. The University of Louisville is located in Louisville, Kentucky with a growing community, which exceeds 22,000 students. The 
University of Louisville is considered to be the most diverse institution of higher education within the state of Kentucky (personal communication, Mordean TaylorArcher, May 12, 2011). According to the University of Louisville, Fall 2010 enrollment, the total African American population consists of 2,363 students (10.6\%); with an African American faculty population of 126 members (Uofl Institutional Research, 2010).

\section{Instrumentation}

The researcher used a survey based upon the Institutional Integration Scale Survey designed by Pascarella and Terenzini (1980). Pascarella and Terenzini (1980) used this survey instrument in earlier studies to identify factors, which influenced students' persistence in college. The five scales survey instrument was created based upon Tinto's $(1975,1987,1993)$ models. It has been used and validated to conduct research study on student persistence factors (Fox, 1984). The adaptations of the survey used focus on the same aspect while placing emphasis on their attitude and involvement within the C.O.N.E.C.T. Peer Mentor Program. The instrument was constructed based upon 83 variable items, using 5-point Likert-Type scale for measurement with ' 5 ' as strongly agree and ' 1 ' as strongly disagree. The students were asked to respond to a survey questionnaire to illustrate their viewpoints regarding their academic and social integration.

The independent variables were grouped in three categories: Academic, Social, and Institutional/Goal Commitment Integration. Additionally, the pre-college attributes were also measured. Such attributes include Gender (Gen), High School GPA (HSGPA), Parental Income (Income), Mother and Father's academic highest attainment of education 
(MHD and FHD, consecutively), Classification (CLASS), Student's highest expected degree (HIGHESTDEGREE) as well as the importance of attending the University of Louisville (UNIVATTEND).

The Social integration (SI scale) is determined using questions 1-2,8, 12-13, 17-18, and 41 through 43 . The scale measures interactions with their peers and with faculty. The Academic Integration scale (AI scale) is determined using questions 40, 44, 47, 51, 52, $59,61,70,72$ and 73 . This scale was based upon academic and intellectual development. The Institutional and Goal Commitment (IGC scale) is determined by questions 9, 11, 24, $27,66-69,82$, and 83 . This scale was based upon feelings towards institutional and commitment to graduation. There were a total of 30 questions used to measure the academic, social, and institutional/goal integration; ten questions per scale.

\section{Procedures for Collection of Data}

The first step in collecting data was gaining approval from IRB in order to interview and the survey students based off of Pascarella and Terenzini's (1980) Institutional Integrated Scale Survey. Secondly, the researcher contacted the C.O.N.E.C.T. peer mentor's supervisor, Dr. Tomarra Adams, receive approval to survey students and interview her peer mentors in regards to the study. Then the researcher visited a staff meeting in order to poll possible participants.

Prior to distributing information regarding access to the online survey to participants, the researcher disseminated survey guidelines to each student. The researcher explained that only sophomore, junior, and senior students who currently serve as C.O.N.E.C.T. peer mentors could participate in the study. Additionally, the students 
were told at any point, they were able to decline answering any questions that causes them to be uncomfortable. However, this study did not use any data from surveys that were not completely answered. After participants completed their surveys, the interview process occurred. The nine students were interviewed based upon their availability during an outline time frame. The surveys were grouped by classification. 


\section{CHAPTER THREE}

Findings

Chapter Two describes the population, data collection instrument, procedures for collection of data, and the number of participants of the study. The purposes of the study were to: a) examine the relationship between being a peer mentor and academic success beyond the during the first year experience; and b) to examine the relationship between social integration of $2^{\text {nd }}$ year students in the C.O.N.E.C.T. Mentor Program with their academic integration. The study is significant because it examined the intersection of race within the context of the sophomore slump with peer mentoring as an initiative to address the issue of retention.

\section{Demographic Data}

Question 2 asked the participants their gender. All sixteen participants were female. Question 5 asked the participants their year of enrollment at the University of Louisville. Frequencies and percentage totals are presented in Tables 2 . The responses are separated by mentoring status; mentors' responses are provided first followed by the total sample. The majority $(60 \%)$ of the mentoring participants were third year student and half of the sample of participants was third year students. The second year students represented $25 \%$ of the sample population. 


\section{Table 2}

Frequencies and percentage of years of enrollment at the University of Louisville

\begin{tabular}{|c|c|c|c|c|c|c|c|c|}
\hline \multirow[t]{2}{*}{ Mentor Status } & \multicolumn{2}{|c|}{$2^{\text {nd }}$ Year } & \multicolumn{2}{|c|}{$3^{\text {rd }}$ Year } & \multicolumn{2}{|c|}{$4^{\text {th }}$ Year } & \multicolumn{2}{|c|}{$5^{\text {th }}$ Year } \\
\hline & $\mathrm{N}$ & $\%$ & $\mathrm{~N}$ & $\%$ & $\mathrm{~N}$ & $\%$ & $\mathrm{~N}$ & $\%$ \\
\hline Non-Mentor & 2 & 33.3 & 2 & 33.3 & 1 & 16.7 & 1 & 16.7 \\
\hline Mentor & 2 & 20 & 6 & 60 & 2 & 20 & 0 & 0 \\
\hline
\end{tabular}

Question 6 asked the participants their high school GPA. Frequencies and percentage totals for high school GPA are presented in Tables 3 . The majority $(90 \%)$ of mentor participants had GPA scores between 3.0 and 3.9. Table 3.2 offers the frequencies and percentage totals of high school GPA for the total sample population. The majority (50\%) of the non-mentors also reported GPA scores between 3.0 and 3.9. All participants' GPAs were self-reported.

\section{Table 3}

Frequencies and percentage of high school GPA

\begin{tabular}{|c|c|c|c|c|c|c|c|c|}
\hline \multirow[t]{3}{*}{ Mentor Status } & \multirow{2}{*}{\multicolumn{2}{|c|}{4.0}} & \multirow{2}{*}{\multicolumn{2}{|c|}{$3.0-3.9$}} & \multirow{2}{*}{\multicolumn{2}{|c|}{$2.0-2.9$}} & \multirow{2}{*}{\multicolumn{2}{|c|}{ Below 1.5}} \\
\hline & & & & & & & & \\
\hline & $\mathrm{N}$ & $\%$ & $\mathrm{~N}$ & $\%$ & $\mathrm{~N}$ & $\%$ & $\mathrm{~N}$ & $\%$ \\
\hline Non-Mentor & 1 & 16.7 & 3 & 50 & 2 & 33.3 & 0 & 0 \\
\hline Mentor & 0 & 0 & 9 & 90 & 1 & 10 & 0 & 0 \\
\hline
\end{tabular}

During the interview the participants were asked to describe their classification as well their year of involvement with the CONECT peer mentoring program. Frequencies and percentage totals are presented in Tables 4 . The majority (70\%) of respondents were first year mentors. 


\section{Table 4}

Frequencies and percentage of C.O.N.E.C.T. peer mentor year of involvement and classification

\begin{tabular}{|c|c|c|c|c|c|c|}
\hline & \multicolumn{2}{|c|}{ Sophomore } & \multicolumn{2}{|c|}{ Junior } & \multicolumn{2}{|c|}{ Senior $(4+$ years $)$} \\
\hline & $\mathrm{N}$ & $\%$ & $\mathrm{~N}$ & $\%$ & $\mathrm{~N}$ & $\%$ \\
\hline First Year Mentor & 2 & 20 & 4 & 40 & 1 & 10 \\
\hline Second Year Mentor & 0 & 0 & 2 & 20 & 1 & 10 \\
\hline
\end{tabular}

Questions 7-9 asked the participants their attainment of scholarship awards. Majority (90\%) of the participants were awarded full scholarships. All the scholarship recipients were members of the Woodford R. Porter Scholarship Program; a scholarship granted to African American high school seniors in Kentucky who demonstrate academic and leadership excellence. Majority (70\%) of the participants maintained their scholarships. The one participant not awarded a scholarship is a transfer student and was ineligible for the scholarship because it is only awarded to Kentucky incoming first year students only. Scholarship status was self-reported. The frequencies and percentages are represented in Table 5 .

\section{Table 5}

\section{Frequencies and Percentages for Scholarship renewal}

\begin{tabular}{cccccccccc} 
Mentor Status & \multicolumn{2}{c}{ Not Applicable } & & \multicolumn{2}{c}{ No } & & \multicolumn{2}{c}{ Yes } \\
\cline { 2 - 5 } \cline { 6 - 8 } & & $\mathrm{N}$ & $\%$ & & $\mathrm{~N}$ & $\%$ & & $\mathrm{~N}$ & $\%$ \\
\hline Non-Mentor & 2 & 33.3 & & 1 & 16.7 & & 3 & 50 \\
Mentor & 1 & 10 & & 2 & 20 & & 7 & 70 \\
\hline
\end{tabular}

Question 10 asked participants their parents' income. The majority (60\%) of mentor participants' had parental incomes that were between $\$ 30,001$ and $\$ 60,000$ 
dollars annually. The majority $(50 \%)$ of the non-mentor participants reported an income less than $\$ 30,000$. Frequencies and percentage totals are presented in Table 6. Data was self-reported.

\section{Table 6}

Frequencies and Percentages for Parental Income

\begin{tabular}{|c|c|c|c|c|c|c|c|c|}
\hline \multirow[t]{2}{*}{ Mentor Status } & \multicolumn{2}{|c|}{$\begin{array}{l}\text { Less than } \\
\$ 30,000\end{array}$} & \multicolumn{2}{|c|}{$\begin{array}{c}\$ 30,001 \text { to } \\
\$ 60,000\end{array}$} & \multicolumn{2}{|c|}{$\begin{array}{c}\$ 60,001 \text { to } \\
\$ 90,000\end{array}$} & \multicolumn{2}{|c|}{$\begin{array}{l}\$ 90,001 \text { to } \\
\$ 120,000\end{array}$} \\
\hline & $\mathrm{N}$ & $\%$ & $\bar{N}$ & $\%$ & $\mathrm{~N}$ & $\%$ & $\mathrm{~N}$ & $\%$ \\
\hline Non-Mentor & 3 & 50 & 2 & 33.3 & 0 & 0 & 1 & 16.7 \\
\hline Mentor & 2 & 20 & 6 & 60 & 2 & 20 & 0 & 0 \\
\hline
\end{tabular}

Question 11 asked the participants describe their college selection choice.

Frequencies and percentage totals are presented in Table 7. Seventy percent of the participants described the University of Louisville to be within their top five choices while the remaining thirty percent reported the institution to be their first choice.

\section{Table 7}

Frequencies of rank of University's choice

\begin{tabular}{|c|c|c|c|c|c|c|}
\hline \multirow[t]{2}{*}{ Mentor Status } & \multicolumn{2}{|c|}{ First Choice } & \multicolumn{2}{|c|}{ Second Choice } & \multicolumn{2}{|c|}{ Top Five } \\
\hline & $\mathrm{N}$ & $\%$ & $\mathrm{~N}$ & $\%$ & $\mathrm{~N}$ & $\%$ \\
\hline Non-Mentor & 0 & 0 & 2 & 33.3 & 4 & 66.7 \\
\hline Mentor & 3 & 30 & 0 & 0 & 7 & 70 \\
\hline
\end{tabular}

Question 12 asked participants their highest expected degree. As shown in the table below, all the participants expect to earn an advanced degree. Eighty percent of the mentor participants intend to earn a doctorate degree. Fifty percent of the non-mentors 
intend to earn a doctorate degree. The frequencies and percentages are illustrated in Table 8.

\section{Table 8}

Frequencies of mentors' highest expected academic degree

\begin{tabular}{|c|c|c|c|c|c|c|c|c|}
\hline \multirow[t]{2}{*}{ Mentor Status } & \multicolumn{2}{|c|}{ Bachelors } & \multicolumn{2}{|c|}{ Masters } & \multicolumn{2}{|c|}{ M.D. } & \multicolumn{2}{|c|}{ Ph.D } \\
\hline & $\mathrm{N}$ & $\%$ & $\mathrm{~N}$ & $\%$ & $\mathrm{~N}$ & $\%$ & $\mathrm{~N}$ & $\%$ \\
\hline Non-Mentor & 0 & 0 & 3 & 50 & 0 & 0 & 3 & 50 \\
\hline Mentor & 0 & 0 & 2 & 20 & 1 & 10 & 7 & 70 \\
\hline
\end{tabular}

Questions 13 and 14 asked participants regarding their parents' highest level of attainment. Frequencies and percentages for parental education are summarized in Tables 9 and 10 . The majority $(60 \%)$ of the mentor participants' mothers had an associate degree. On the other hand, the mentor participants' fathers displayed a variety of degree attainment. Thirty percent of their fathers' obtained their high school diploma and thirty percent attained a post-secondary degree. The non-mentor participants' mother's level of education varied; however, majority obtained degrees beyond their high school diplomas. The majority (50\%) of non-mentor participants' fathers obtained their high school diploma. 
Table 9

Frequencies and Percentages for Mothers' Education by Mentoring Status

\begin{tabular}{|c|c|c|c|c|c|c|c|c|c|c|c|c|}
\hline \multirow[t]{2}{*}{$\begin{array}{l}\text { Mentor } \\
\text { Status }\end{array}$} & \multicolumn{2}{|c|}{$\begin{array}{c}\text { Not } \\
\text { Applicable } \\
\end{array}$} & \multicolumn{2}{|c|}{ HS/ GED } & \multicolumn{2}{|c|}{ Associate } & \multicolumn{2}{|c|}{ Bachelors } & \multicolumn{2}{|c|}{ Masters } & \multicolumn{2}{|c|}{ Doctorate } \\
\hline & $\mathrm{N}$ & $\%$ & $\overline{\mathrm{N}}$ & $\%$ & $\overline{\mathrm{N}}$ & $\%$ & $\mathrm{~N}$ & $\%$ & $\mathrm{~N}$ & $\%$ & $\mathrm{~N}$ & $\%$ \\
\hline Non- & 0 & 0 & & & 2 & 33.3 & 2 & 33.3 & 1 & 16.7 & 0 & 0 \\
\hline Mentor & & & & & & & & & & & & \\
\hline Mentor & 0 & 0 & 3 & 10 & 6 & 60 & 0 & 0 & 1 & 10 & 0 & 0 \\
\hline
\end{tabular}

Table 10

Frequencies and Percentages for Fathers' Education by Mentoring Status

\begin{tabular}{|c|c|c|c|c|c|c|c|c|c|c|c|c|}
\hline \multirow[t]{2}{*}{$\begin{array}{c}\text { Mentor } \\
\text { Status }\end{array}$} & \multicolumn{2}{|c|}{$\begin{array}{c}\text { Not } \\
\text { Applicable } \\
\end{array}$} & \multicolumn{2}{|c|}{ HS/ GED } & \multicolumn{2}{|c|}{ Associate } & \multicolumn{2}{|c|}{ Bachelors } & \multicolumn{2}{|c|}{ Masters } & \multicolumn{2}{|c|}{ Doctorate } \\
\hline & $\mathrm{N}$ & $\%$ & $\bar{N}$ & $\%$ & $\mathrm{~N}$ & $\%$ & $\mathrm{~N}$ & $\%$ & $\bar{N}$ & $\%$ & $\mathrm{~N}$ & $\%$ \\
\hline Non- & 2 & 33.3 & 3 & 50 & 1 & 16.7 & 0 & 0 & 0 & 0 & 0 & 0 \\
\hline \multicolumn{13}{|l|}{ Mentor } \\
\hline Mentor & 2 & 20 & 3 & 30 & 2 & 20 & 1 & 10 & 2 & 20 & 0 & 0 \\
\hline
\end{tabular}

Questions 15 and 16 asked participants the importance of attend the University of Louisville as well as the importance of graduating. Eighty percent of the mentor participants placed the importance of attending UofL as very important; however, all of the participants placed a great deal of importance of graduating. Frequencies and percentage totals are demonstrated in Table 11. 
Table 11

Frequencies and Percentages of Level of Importance of graduating from UofL

\begin{tabular}{|c|c|c|c|c|c|c|c|c|}
\hline \multirow[t]{2}{*}{ Mentor Status } & \multicolumn{2}{|c|}{ Very Important } & \multicolumn{2}{|c|}{ Important } & \multicolumn{2}{|c|}{$\begin{array}{l}\text { Moderately } \\
\text { Important }\end{array}$} & \multicolumn{2}{|c|}{ Unimportant } \\
\hline & $\mathrm{N}$ & $\%$ & $N$ & $\%$ & $\mathrm{~N}$ & $\%$ & $\mathrm{~N}$ & $\%$ \\
\hline Non-Mentor & 6 & 100 & 0 & 0 & 0 & 0 & 0 & 0 \\
\hline Mentor & 10 & 100 & 0 & 0 & 0 & 0 & 0 & 0 \\
\hline
\end{tabular}

Findings by Research Questions

In order to understand the impact of mentoring in regards to social and academic integration, the researcher used three scales and each scale has a group of questions assigned. Scale 1 represents a group of questions related to interaction with peers and faculty members as well as their concern towards the development of the student. Scale 2 represents questions regarding their perception of academic and intellectual development. Scale 3 represents a group of questions that explores the student's perception of institutional commitment. The first scale is used to measure social integration factors, while scales two and three measures academic integration factors.

As a result of having a small sample size, a standard Pearson correlation test was conducted in order to examine the relationship between mentoring status and academic and social integration. Mentoring status was explained using a dummy variable; nonmentors were assigned a value of ' 0 ' while mentors were assigned a value of ' 1 .' The Pearson test revealed a significant relationship between mentoring status and academic integration. There was no significant relationship shown between mentoring and social or institutional/goal commitment. However, there is a significant strong relationship between academic and social integration. Therefore, the academic boost from 
involvement in the mentoring program will also promote stronger sense of social integration.

\section{Table 12}

Correlation between mentoring status and social integration, academic integration, and institutional goal commitment.

\section{Correlations}

\begin{tabular}{|c|c|c|c|c|c|}
\hline & & MentStatus & SocInteg & AcadInteg & $\begin{array}{c}\text { InstGoalCo } \\
\mathrm{mm}\end{array}$ \\
\hline \multirow[t]{3}{*}{ MentStatus } & $\begin{array}{l}\text { Pearson } \\
\text { Correlation }\end{array}$ & 1 & .278 & $.571^{*}$ & .070 \\
\hline & Sig. (2-tailed) & & .297 & .021 & .795 \\
\hline & $\mathrm{N}$ & 16 & 16 & 16 & 16 \\
\hline \multirow[t]{3}{*}{ SocInteg } & $\begin{array}{l}\text { Pearson } \\
\text { Correlation }\end{array}$ & .278 & 1 & $.777^{* *}$ & .238 \\
\hline & Sig. (2-tailed) & .297 & & .000 & .375 \\
\hline & $\mathrm{N}$ & 16 & 16 & 16 & 16 \\
\hline \multirow[t]{3}{*}{ AcadInteg } & $\begin{array}{l}\text { Pearson } \\
\text { Correlation }\end{array}$ & $.571^{*}$ & $.777^{* *}$ & 1 & .170 \\
\hline & Sig. (2-tailed) & .021 & .000 & & .529 \\
\hline & $\mathrm{N}$ & 16 & 16 & 16 & 16 \\
\hline \multirow[t]{3}{*}{$\begin{array}{l}\text { InstGoalCmt } \\
\text { ment }\end{array}$} & $\begin{array}{l}\text { Pearson } \\
\text { Correlation }\end{array}$ & .070 & .238 & .170 & 1 \\
\hline & Sig. (2-tailed) & .795 & .375 & .529 & \\
\hline & $\mathrm{N}$ & 16 & 16 & 16 & 16 \\
\hline
\end{tabular}

*. Correlation is significant at the 0.05 level (2-tailed).

**. Correlation is significant at the 0.01 level (2-tailed).

The participating mentors provided access to their official transcripts in order to view the trends in their academic record. Based upon their averages gathered prior to and during their involvement into the CONECT Peer Mentoring Program, the majority (60\%) of the mentors experienced a positive change in their academic performance after their 
involvement in the program. Though there were positive changes with the majority of mentors, both sophomores experienced a negative change. However, it is important to note that during the time of this study, the sophomores' transcripts only reported their fall semester grades. During the interviews, both acknowledged their struggle to adjust to a new leadership role.

In order to measure the social integration, academic integration and institutional and goal commitment of the participants, the subjects along with their responses were transposed into an excel sheet in order to see the variance in responses between the mentor and non-mentor sample. Within the excel worksheet, a summation and average was taken in order to numerically compare the variance. The survey was weighed using a 5-point Likert-Type scale for measurement with ' 5 ' as strongly agree and ' 1 ' as strongly disagree. The students were asked to respond to a survey questionnaire to illustrate their viewpoints regarding their academic and social integration. It is important to note questions $12,13,51,52,61$ and 63 were presented using negative connotation, therefore, the Likert-scale was inverted in order to reflect true response.

The SI scale was constructed to gauge the interaction of the participants with their peers as well as faculty. The scale was created using questions 1-2,8, 12-13, 17-18, and 41 through 43. The excel sheet showed similarities in responses regarding social integration. Therefore, responses that varied $>0.6$ were examined closely. Questions 8 , 13,17 , and 41 varied significantly. The mentor sample strongly agreed they would describe their personal relationships at the University of Louisville as satisfying with an average of 4.7; opposed to the non-mentor sample who averaged a 4.0. When comparing the results according to classification, sophomore mentors averaged a 5.0 compared to 
sophomore non-mentors with a 3.5. When asked about understanding and sharing similar values with peers, the mentor sample averaged a 4 opposed to the 3.3 averaged by the non-mentor sample.

Question 13 surveyed the degree of difficulty, which the participants encountered when trying to become involved. The mentor sample averaged 4.6 while the non-mentor sample averaged a 3.8. When examining the variance among the classifications, nonmentor seniors experienced less difficulty; however, sophomore mentors averaged a 4.5 compared to non-mentor sophomores with a 3.0. When asked about feelings towards the racial climate at the University of Louisville, the non-mentor sample experience a higher level of comfort. The trend fluctuated within the mentor sample; sophomores and seniors were neutral while juniors experienced discomfort with the racial climate. The nonmentor sample experienced a steady trend; the sophomores were comfortable with the racial climate, averaging a 4.0 while juniors were neutral. During the non-mentor sample's senior years, they reported an average of 2.5 .

In regards to interaction with faculty and staff at the University of Louisville, majority of the participants indicated a positive relationship. However, the mentor sample reported higher interaction with the faculty and staff as well as having a greater rapport with members.

The greatest variance was shown in regards to academic integration for the participants. The Academic Integration scale (AI scale) is determined using questions 40, $44,47,51,52,59,61,70,72$ and 73 . This scale was based upon academic and intellectual development. The greatest level of variance was indicated by questions $40,52,61,72$ and 73. Question 40 asked the participants to if they felt academic advising has helped them a 
great deal. The mentor sample strongly agreed, averaging a 4.7 while the non-mentor sample averaged a neutral score of 3.3. Sophomore and senior mentors along with nonmentoring seniors averaged a 4.5; however, the greatest average reported came from junior mentors with 4.8. The non-mentoring juniors reported the lowest average with 2.5 while the non-mentor sophomore were neutral in the matter.

When surveyed regarding perceived effort, non-mentors believed they had to work harder. The perceived effort of the participants may be a result of anxiety experienced within the classroom setting. Non-mentor sophomores and juniors experienced some anxiety in the classroom; whereas, mentors did not report experiencing any anxiety. These factors may be linked to thoughts of quitting school. Sophomore mentors expressed the highest resistance to thoughts of quitting school while non-mentoring sophomores were neutral. Overall, the mentor sample reported a positive academic experience, whereas; the non-mentoring sample reported a neutral average.

The Institutional and Goal Commitment (IGC scale) is determined by questions 9 , $11,24,27,66-69,82$, and 83 . This scale was based upon feelings towards institutional and commitment to graduation. Upon review of questions regarding institutional and goal commitment, it is evident that the participants believe the University of Louisville is commited to the goal of educating the student population. However, there are varying view regarding commitment to graduation. The non-mentoring sample strongly believed graduation equated to success; whereas; the mentors did not share such strong beliefs. However, the mentor sample unanimously believed they would graduate from the university contrary to the non-mentoring sample that reported fluctuating responses. Interview Results 
1. Why did you become a peer mentor and what was your previous experience with peer mentoring?

Students chose to serve as a peer mentors for various reasons. Most students considered their previous mentoring experience to be their driving force, both positive and negative. Majority of the students attributed their success to having a successful relationship with their CONECT mentor during their first year. Consequently, they wanted to share in that capacity in order to assist students who are in a similar position. Two students expressed that their peer mentoring experience was not completely successful. Their mentors were inconsistent with their contacts. As a consequence, they wanted to provide other students with a positive peer mentoring experience.

2. As a mentee and now as a mentor, how beneficial has your mentoring experiences been?

Students expressed that their mentoring experiences were beneficial. As mentees, they expressed how they felt comfort knowing that there was someone available to assist them whenever an issue arose or if they just needed someone to talk with. As mentors, all the respondents conveyed having capable advisors available was a major benefit. All the students alluded to the personal and academic support demonstrated by their advisors. They also explained how having their mentees look up to them causes them to carry themselves in a positive manner. Overall, each mentor expressed that their positions as often them with responsibility and their advisors as well as their mentees hold them accountable. They also gave details regarding their sense of reward from performing a good deed.

Interestingly, one mentor who was a sophomore explained that her involvement with the CONECT peer-mentoring program gave her an identity. Furthermore, emphasizing 
how important it is for students, especially sophomores to be recognized by the university.

3. What did you do to establish a relationship with your mentees?

a. How did your efforts to build those relationships with your mentees work in actually establishing a relationship with your mentees?

b. How do you feel these relationships impacted your own experiences at the University? Has you relationship with your mentees impacted how you view yourself?

CONECT peer mentor sought to establish a relationship through meeting their mentees during the Porter College Week, the week before the start of the fall semester created to help orient recipients of the Woodford R. Porter Scholarship. After orientation sessions and Porter College week, mentors begin to meet with their mentees on a one-onone basis in order to establish a personal connection and get an understanding of the type of person they were. While some students were responsive, while others were not; therefore, mentors sought them out via text messages, email and social networks (i.e. facebook and twitter.)

Upon initial meetings, mentors sought to allow the students to see who they as individuals. One student explained how she wanted her students to understand how she is 'just a student like them.' Other mentors shared her sentiments, illustrating how transparency is key to establishing a relationship with their mentees. The students expressed that their efforts were noted by their mentees and majority of their mentees are active within the program and have a relationship with their mentors.

All the mentors alluded to the concept of accountability when reflecting upon their personal growth. Majority of the mentors professed that they were typically shy in social and academic settings; however, they felt as though they could not ask their mentees to 
perform actions they were not willing to do. Those who were already active individual explained how they sought to carry themselves with a great sense of respect since they represented the program.

4. What were the expectations and responsibilities placed upon you as a CONECT peer mentor?

The CONECT peer mentors described how they are held to great expectation, academically and socially. The program requires the mentors to maintain at least a 2.5 GPA; however, many expressed that their scholarship requires a 3.0 GPA. Socially the mentors felt like they had to demonstrate their leadership skills in every aspect of their student life; i.e. within and outside student organizations.

5. What were some of the challenges you faced as a peer mentor?

The mentors explained that their greatest challenge was addressing mentees that did not reciprocate interest in their help. One mentor explained, "the hardest part of mentoring is the feeling of responsibility for others and not being able to connect with them as a result of avoidance."

6. How were able to overcome your challenges?

The mentors expressed that they often addressed their challenges with one of their advisors. It was conveyed that their advisors were always open and provided with sound advice. Two students conveyed that they internalized their frustration and continue to work towards reaching their mentees.

7. Explain the academic and personal support you received, if any, as a peer mentor?

8. Describe your relationship with:

a. Fellow CONECT peer mentors

b. CONECT Advisors 
The mentors explained that they received both academic and personal support as CONECT peer mentors. Their academic support was in the form of priority registration and their accessibility to two academic advisors to assist them with decisions regarding academic requirements and decisions. The also explained how they received personal support in two forms: from their fellow peer mentors and from their advisors. All of the mentors explained that they had a core group of peers within the organization who shared like values. Even if the mentors were not close friends, they explained a sense of respect towards all. One mentor explained CONECT 'forced them to work together' in order to have a successful program. Another mentor stressed the importance of having an established group of peers she could rely on for support. She stated,

"we (CONECT peer mentors) took classes together and we were able to talk about class after the (staff) meetings and that was what helped me a lot because a lot times I want to go up to people to talk about things in class but I don't necessarily know them...having people in CONECT and in class is really good because you can talk about it outside of class. We got together a really good study group...my grades have improved a whole a lot since being in CONECT."

The mentors expressed their accessibility to their advisors who provide them with personal support. In the eyes of the mentors, the advisors serve as role models for them. They described the extent to which their advisors were willing to go to assist them in their development. The students highlighted how one of their advisors serves in multiple positions on campus and as a result was not able to dedicate a great deal of time to the program due to other leadership and professional obligations. However, her merit gives them a standard, which they strive towards. This illustrates the pressure of responsibilities placed upon African American faculty members.

9. Have you developed since becoming a CONECT peer mentor? 
a. How?

10. Upon becoming a CONECT peer mentor, did your performance in the classroom change (i.e. attendance, participation, interaction with professors and classmates)?

a. Outside the classroom?

b. Overall campus community?

The mentors emphasized a great deal of development regarding their problem-solving skills. The conveyed how they understood their advice could and would play a role upon their mentees therefore, the sought to provide sound advice. Once again the mentors explained that they did not believe in asking certain actions of their mentees that they did not perform. Therefore, some of their behaviors had to change upon becoming a CONECT peer mentor. One mentor explained that prior to becoming a CONECT peer mentor she did not attend classes on a regular basis; however, she realized that her mentees were watching her closely and held her responsible for her actions. That sense of accountability was a reoccurring theme expressed by all of the mentors.

11. Please compare and contrast the differences between being a part of the CONECT peer mentoring community and being a part of the campus community as a whole?

CONECT was explained to be somewhat of a safe haven for the mentors. The campus community is considered to be large and overwhelming while CONECT provides a true sense of belonging through an intimate setting. One mentor stated,

"CONECT wants to develop relationships with students and they care about the betterment of the students academically wise...in the Biology department, I feel like you don't get the sense of professors caring about your betterment, they just care about the subject. CONECT reaches out a hand and genuinely cares about your success in college, personally, socially, and academically."

12. What is your primary goal as a student at the university and how has being mentor helped you make progress in achieving it? 
All of the mentors expressed that their primary goal was to graduate. They believe being a mentor helps them to progress towards their goal through maintaining the GPA requirement for participation, networking with faculty and staff, developing leadership skills, and experience working with different people.

13. What were your expectations of college when you arrived? How do they compare with what you've experience thus far?

Mentors based their expectations of college upon two concepts: media and experiences shared by others. Students believed that college would be 'a lot of fun' however demanding academically. Mentors expressed that their expectations were generally right. The have managed to have fun while balancing the academic demands. The mentors also addressed the concept of diversity, which is emphasized by the University of Louisville. One student stated,

"I don't believe they (the University of Louisville administrators) listen, I don't believe that Black people have as much power as we think we do...things haven't changed...things like blackface keep happening...however, the situation is merely tolerated. They (the University of Louisville) like to call themselves diversified...our campus is diverse in the sense that people of all different cultures but most of the programs are not geared towards any minorities. Things that Black people ask for and need like expansion to the cultural center is not addressed. 


\title{
CHAPTER FOUR
}

\author{
Summary and Recommendations
}

Summary

The purpose of this study is to examine retention of African American peer mentors who persist beyond their freshmen year using social and academic integration scale factors in order to contribute to their experiences as peer mentors and their overall persistence combating symptoms of the sophomore slump. The study is significant because it examined the intersection of race within the context of the sophomore slump with peer mentoring as an initiative to address the issue of retention. The study used sophomore, junior and senior college students as participants in order to have a comparative analysis. The researcher used Drs. Pascarella and Terenzini's integration scale, which in based upon Tinto's retention model, as the primary instrument for analyzing and interpreting of data and identified usages of Collin's (2000) theoretical framework of other-mothering.

\section{Conclusions}

The following conclusions were based on the data reported in Chapter Three. The findings revealed the differences in social integration, academic integration, and institutional and goal commitment scale factors by the mentors and non-mentor sample in different classification. The data collected demonstrated that the sophomore slump impacts the African American student population and is heightened with the difficulty of adjusting to a predominately white institution. 
Though the participants of this study face a number of obstacles related to the sophomore slump, it is important to note that those problems are faced at every level of matriculation. Tinto's theory of student retention was upheld within this study. The participants conveyed that their continued matriculation is based upon their ability to socially and academically perform at the university. They also demonstrate the will to continue studies regardless of the obstacles faced.

The survey in addition to the interviews suggested that majority of peer mentors receive a great deal of support from peers and advisors which plays an influential role in their academic integration, social integration, as well as their commitment to the institution and graduation. Previous research suggests African American students are reluctant to confide or look up to Caucasian advisors; however, within the C.O.N.E.C.T. Peer Mentor Program, that is not the case. One of the primary advisors is Caucasian and serves the African American peer mentor cohort effectively. The mentors convey the importance of having a space in order to address their needs as well as the needs of their mentees. Their established roles as mentors provide them with a sense of purpose and identity, which is an important factor during matriculation especially during the second year experience.

\section{Limitations}

It is important to note there were a few limitations encountered during the course of the study. First, the sample drawn for the group and individual interviews were based upon ten C.O.N.E.C.T. Peer Mentors who ranged from sophomores to seniors. The C.O.N.E.C.T. Peer Mentoring Program consists of 22 mentors; however, only ten were committed to full participation. Additionally, in order to establish a comparative study, 
snowball sampling was used to gather a basis for a non-mentor group at the University of Louisville. Majority of the non-mentor participates were friends or associates of the mentors; thus, exposed to similar experiences.

Secondly, all of the participants involved in this study were African American female. During the time of this study, of the 22,290 students enrolled at the university, only 2,363 were African American students (http://louisville.edu/about/profilel.html\#facts). Of the total student population, $10.6 \%$ were African American; however, no information is available regarding the gender breakdown. Regardless, the results of this study only portray the views of African American females. The results of the study may have been different if the perspective of African American males were represented.

Lastly, due to the timing of the study, many of the non-mentors were in the midst of finals and as a result only one non-mentor participant submitted their follow-up responses. Therefore, the results of the study may have been different if the perspective of other non-mentors were available.

\section{Recommendations for Higher Education Institutions}

1. Institutions should examine how motivation (extrinsic vs. intrinsic) affects gender among African American peer mentors.

2. The University of Louisville should enforce mandatory advising for all undergraduate students regardless of classification to ensure a sense of engagement with staff.

3. Self-exploratory materials like StrengthQuest proved to provide support; therefore, it 
would benefit college introduction classes; i.e. Gen 101, in order to identify strengths, which can help students and faculty understand their potential.

4. The University of Louisville should provide additional funding for the CONECT Peer Mentoring program in order to expand the number advisors and undergraduate peer mentors.

5. Institutions should examine the impact of having graduate students serve as a mentors; the student to student relationship proves to be encouraging and motivating.

6. Institutions should strongly encourage training in regards to addressing students of a diverse background in order to properly understand and address their academic and social needs. 


\section{REFERENCES}

Allen, W.R. (1992). The color of success: African American college student outcomes at predomintly white and historically black public college and universities. Harvard Educational Review, 64(1), 26-44.

Ancis, J. R. (2000). Student perceptions of campus cultural climate by race. Journal of Counseling Development , 78, 180-185.

Astin, A.W. (1996). Involvement in learning revisited: Lessons we have learned. Journal of College Student Development, 45(5), 471-478.

Bean, J. (1990). Using Retention Management in Enrollment Management. San Francisco: Jossey Bass.

----, 2006. Black Student College Graduation Rates Inch Higher but a Huge Racial Gap Persists Source: The Journal of Blacks in Higher Education, No. 54 (Winter, 2006/2007), pp. 58-66 Published by: The JBHE Foundation Stable URL: http://www.jstor.org/stable/2507359. Accessed: 03/09/2010 19:56

Bradley, N. (1967). The Negro undergraduate student: factors relative to performance in predominantly White state colleges and universities in Tennessee. Journal of Negro Education, 36, 15-23.

Braxton, J., Mundy, M. (2002). Powerful institutional levers to reduce college student departure. Journal of College Retention, 3 (1), 91-118.

Cokley, K. (2003). What do we know about the motivation of African American students? Challenging the 'anti-intellectual' myth. Harvard Educational Review, $73(4), 524-558$.

Collins, P.H. (2000). Black feminist thought: Knowledge, consciousness, and the politics of empowerment. New York: Routledge.

Davis, R. (1991). Social support networks and undergraduate student academic-success -related outcomes: A comparison of Black students on Black and White campuses. In W. E. Allen, College in Black and White: African American Students in Predominantly White and in Historically Black Public Universitites. (pp. 143-157). Albany, New York: State University of New York. 
Durkheim, E. (1951). Suicide: A study in sociology. (Spalding, J.A., Simpsom, G., trans). New York: Free Press.

Eimers, M. T., \& Pike, G. R. (1996). Minority and non-minority adjustment to college: Differences or similarities? AIR Annual forum Paper. Eric \#ED397707.

Ender, S.C., \& Newton, F.B. (2000). Students helping students: $A$ guide for peer educators on college campuses. San Francisco: Jossey-Bass.

Feldman, K.A. \& Newcomb, T.M. (1969). The impact of colleges upon their students. San Francisco: Jossey-Bass.

Fischer, M.J. (2007). Settling into campus life: Differences by race/ethnicity in college involvement, college satisfaction, and outcomes. Journal of Higher Education, 78(2), 125-161.

Fleming, J. (1984). Blacks in College: A Comparative study of students' success in Black and in White institutions. San Francisco, CA: Jossey-Bass.

Flowers, L. A. (2003). Cognitive Effects of College: Differences between African American and Caucasian Students. Research in Higher Education , 44 (1), 21-49.

Fordham, S. (1988). “Racelessness as a Factor in Black Students' School Success: Pragmatic Strategy or Pyrrhic Victory?" Harvard Educational Review 58:54-84.

Fordham, S. (1996). Blacked Out: Dilemmas of Race, Identity, and Success at Capital High. Chicago, IL: University of Chicago Press.

Fordham, Signithia, and John U. Ogbu. 1986. "'Black Students' School Success: Coping with the Burden of 'Acting White'." Urban Review 18:176-206.

Fox, R. N. (1984). Reliability and discriminate validity of institutional integration scales for disadvantaged college students. Educational and Psychological Measurement, 44, $1051-1057$.

Freedman, M. B. (1956). The passage through college. Journal of Social Issues, 12(4), 13-28.

Graham, S. (1997). Using attribution theory to understand social and academic motivation in African American youth. Educational Psychologist, 32, 21-34.

Guiffrida, D.A. (2003). African American student organizations as agents of social integration. Journal of College Student Development, 44, 304-319.

Guiffrida, D.A. (2004). How involvement in African American student organizations support and hinder academic achievement. NACADA Journal, 24, (1 \& 2), 88-98. 
Guiffrida, D.A. (2005). Othermothering as a framework for understanding African American students' definitions of student-centered faculty. Journal of Higher Education, 76 (6), 701-723.

Harmon, B.V. (2006). A Qualitative Study of the Learning Processes and Outcomes Associated With Students who Serve as Peer Mentors. Journal of the First Year Experience \& Students in Transition. 18 (2), 53-82.

Herrnstein, R., Murray, C. (1994). The Bell Curve: Intelligence and Class Structure in American Life. New York: Free Press.

Heyward, S. (1985). Facilitating the educational development of Black students at predominantly White institutions. Carolina View, 1, 14-18.

Love, K. (2008). Parental Attachments and Psychological Distress Among African American College Students. Journal of College Student Development, 49 (1), 3140.

MacKay, K. A. (1994). A comparison of student effort and education gains of Caucasian and African-American students at predominantly White colleges and universities. Journal of College Student Development , 35, 217-223.

Madrazo-Peterson, R., Rodriquez, M. (1978). Minority students' perception of a university environment. Journal of College Student Personnel , 19, 259-263.

National Center for Education Statistics. (2010). Retrieved February 18, 2011, from http://nces.ed.gov/programs/coe/2010/section2/table-er2-1.asp.

National Center for Education Statistics. (2002). The Condition of Education. Retrieved on February 15, 2011, from http://nces.ed.gov/pubs2002/2002011.pdf.

Nettles, M. T. (1986). Comparative and predictive analyses of Black and White students' college achievement and experiences. Journal of Higher Education , 57, 289 -318 .

Pascarella, E. T. (1979). Interaction effects in Spady's and Tinto's conceptual model of college dropout. Sociology of Education, 52, 197-210.

Pascarella, E. T., \& Terenzini, P. T. (1980). Predicting freshmen persistence and voluntary dropout decisions from a theoretical model. Journal of Higher Education, 52(1), 60-75.

Pattengale, J., \& Schreiner, L. (2000). What is the sophomore slump and why should we care? In Schreiner, L.A. \& Pattengales, J. (eds.). (2000). Visible solutions for invisible students: Helping sophomore succeed. Columbia, SC: University of 
South Carolina, National Resources Center for the First-year Experience and Students in Transition.

Saddlemire, J.R. (1996). Qualitative study of white second semester undergraduates' attitudes toward African American undergraduates at a predominantly white university. Journal of College Student Development, 37 (6), 684-691.

Schaller, M.A. (2005). Wandering and wondering: Traversing the uneven terrain of the second college year. About Campus, 10, 17-24.

Schreiner, L.A. (2010). Factors that contribute to sophomore success and satisfaction. In M.S. Hunter, B.F. Tobolowsky, J.n. Gardner, S.E. Evenbeck, J.A. Pattengale, M.A. Schaller, \& Schreiner (Eds.), Helping Sophomores Succeed: Understanding and Improving the second-year experience. (pp. 43-65). San Francisco: JosseyBass.

Sedlacek, W. (1987). Black students on White campuses: 20 years of research. Journal of College Student Personnel , 28 (6), 484-495.

Slaughter, S. \& Leslie, L.L. (1997). academic capitalism: Politics, Policies, and the Entrepreneurial University. John Hopkins University Press. Baltimore, MD.

Spady, W. (1970, 1971). Dropouts from higher education: An interdisciplinary review and synthesis. Interchange, 1, 64-85.

Taylor-Archer, M. (2011). Personal communication.

Tierney, J.P., Baldwin-Grossman, J., Resch, N.L. (2000). Making a difference: An impact study of big brothers big sisters. Philadelphia: Public Private Ventures research. Review of Educational Research, 45, 89-125.

Tinto, V. (1975). Dropout from higher education: A theoretical synthesis of recent research. Review of Educational Research, 45, 89-125.

Tinto, V. (1987). Leaving College. Chicago, IL: University of Chicago.

Tinto, V. (1993). Leaving College: Rethinking the causes and cures of student attrition ( $2^{\text {nd }}$ ed.). Chicago, University of Chicago Press.

Tracey, T. J. (1984). Noncognitive vaiables in predicting academic success by race. Journal of Measuring Evaluation Guide , 171-178.

University of Louisville. (2010). University profile. Retrieved from http://ouisville.edu/about/profile.html\#facts. 
Upcraft, M.L., Gardner, J.N., \& Barefoot, B.O. (2005). Challenging and supporting the first-year student: $A$ handbook for improving the first year of college. San Francisco: Jossey-Bass.

Vital signs: Statistics that measure the state of racial inequality. (2008, Spring). The Journal of Blacks in Higher Education, 59, 39.

White, C. L. (1988). Ethnic Identity and academic performance among Black and White college students: An interactionist approach. Journal of Urban Education, 23,219 -240 .

Wilder, J. (1993). The sophomore slump: A complex developmental period that contributes to attrition. College Student Affairs Journal, 12(2), 18-27.

Wilson, S. M. (1997). Evaluating the impact of receiving university based counseling services on student retention. Journal of Counseling Psychology, 44 (3), 316-320.

Wolfle, L. M. (1983). Effects of higher education on achievement for Blacks and Whites. Research in Higher Education, 19, 3-9. 
Appendix A

Definition of Terms

1. African American - Refers to people of African descent who were born, raised, and reside in the United States. Term is often used interchangeably with Black.

2. Attrition - Departure from an institution of Higher Education prior to graduation.

3. First-year students - A student who enters the university for the first time with a full-time status

4. Freshmen - Used interchangeably with first-year student; however, within this study it refers to students with up to 30 credit hours of complete coursework.

5. Graduation rate - The percentage of the freshmen cohort completing their undergraduate bachelor's degree at the institution in which they entered as freshmen.

6. Hispanics - Refers to people of Mexican or Spanish descent.

7. Matriculation - Successfully completing one level of study to move on to the next: continued enrollment.

8. Persistence - continual enrollment without breaks or dismissal. 
9. Predominately White Institutions (PWIs) - Refers to an institution of Higher Education where at least $50 \%$ of the undergraduate population is Caucasian.

10. Retention - the institution's ability to retain students upon the time of their graduation without any breaks in study.

11. Second-year students -Students who complete one full year of undergraduate coursework; Fall semester to Fall semester.

12. Sophomores - Used interchangeably with second-year student; completed $30+$ credit hours.

13. Sophomore Slump - Phenomenon that describes the student departure after the second year, a result of a period of uncertainty for the students. 
APPENDIX B

Background Information

1. Name:

2. Gender: A) Female B) Male C) Other

3. Major(s):

4. Minor(s): (if applicable)

5. Classification: A) Second year B) Third year C) Fourth year D) Fifth year

6. High School GPA:
A) $4.0>$ Top $-5 \%$
B) $3.0-3.9$ Top $25 \%$
C) $2.0-2.950 \%$
D) $<1.975 \%$

7. Were you admitted as a scholarship recipient?
A) Yes
B) No

8. Were you admitted as a Porter Scholarship recipient?
A) Yes
B) No

9. If so, are you still a Porter Scholarship recipient?
A) Yes
B) No
C) Not applicable

10. Parental Income:
A) $<\$ 30,000$
B) $\$ 30,001-\$ 60,000$
C) $\$ 60,001-\$ 90,000$
D) $\$ 90,001-\$ 120,000$
E) $\$ 120,001-\$ 150,000$
F) $\$ 150,001>$

11. Attendance at this University was my:
A) First choice
B) Second choice
C) Top five

12. Student's Highest Expected Academic Degree
A) Bachelors
B) Master's
C) $\mathrm{Ph}$. D
E) M.D.
F) J.D. 
13. Mother's Highest Academic Degree
A) Not applicable
B) GED/ HS Diploma
C) Associate
D) Bachelors
E) Master's
F) $\mathrm{Ph} . \mathrm{D}$
G) M.D.
H) J.D.

14. Father's Highest Academic Degree
A) Not applicable
B) GED/ HS Diploma
C) Associate
D) Bachelors
E) Master's
F) $\mathrm{Ph}$. D
G) M.D.
H) J.D.

15. Importance of attending the University
A) Very Important
B) Important
C) Moderately Important
D) Unimportant

16. Importance of Graduating from the University
A) Very Important
B) Important
C) Moderately Important
D) Unimportant 


\section{APPENDIX C}

\section{Survey of integration}

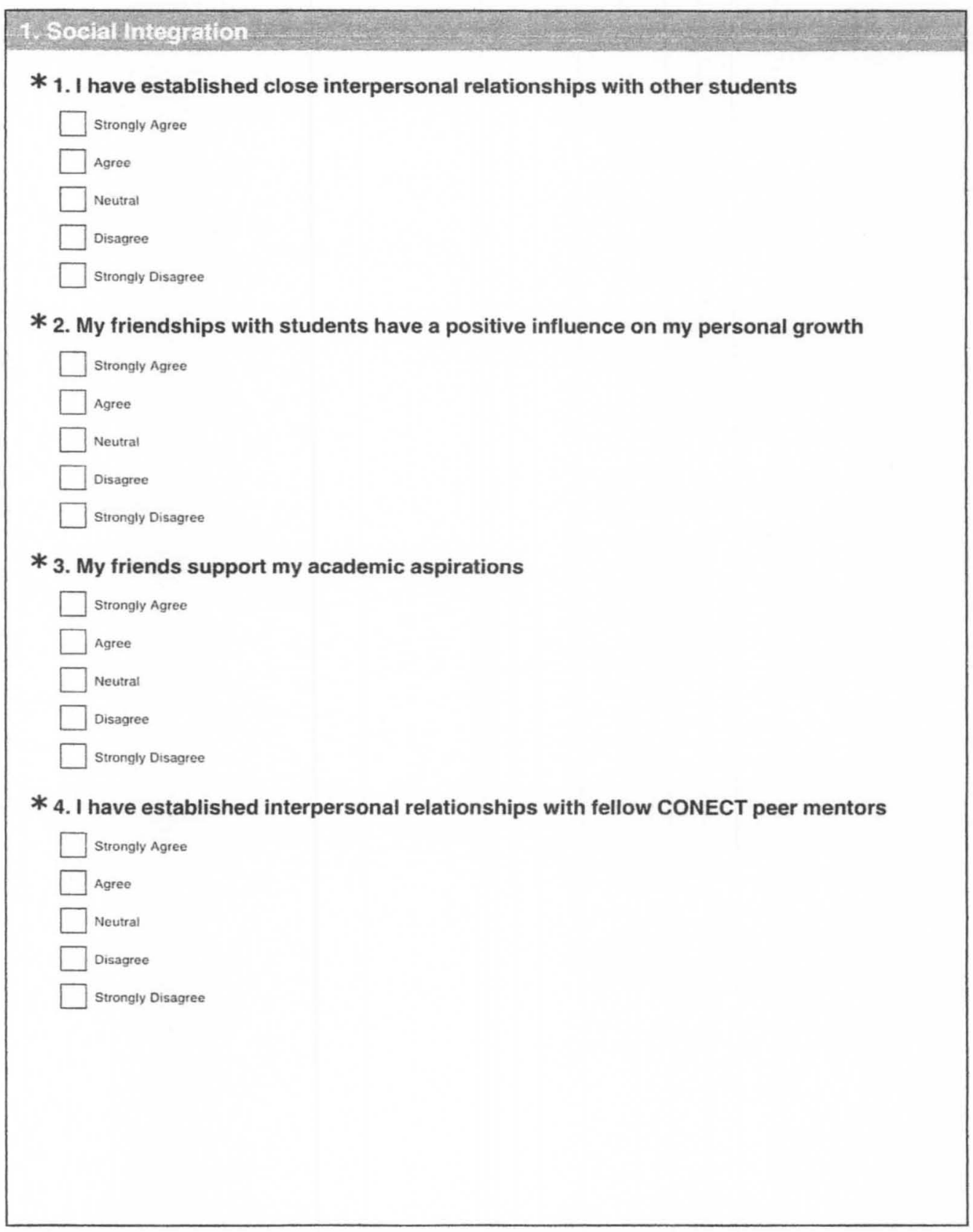


* 5. My fellow CONECT peer mentors had a positive influence on my personal growth

$$
\begin{aligned}
& \square \text { Strongly Agree } \\
& \square \text { Agree } \\
& \square \text { Neutral } \\
& \square \text { Oisagree } \\
& \square \text { Strongly Disagree }
\end{aligned}
$$

* 6. I trust my opinions and values

$$
\begin{aligned}
& \square \text { Stsongly Agree } \\
& \square \text { Agree } \\
& \square \text { Neutral } \\
& \square \text { Disagree } \\
& \square \text { Strongly Disagree }
\end{aligned}
$$

* 7. My fellow CONECT peer mentors admire me

$$
\begin{aligned}
& \square \text { Strongly Agree } \\
& \square \text { Agree } \\
& \square \text { Neutrat } \\
& \square \text { Disagree } \\
& \square \text { Strongly Disagree }
\end{aligned}
$$

* 8 . I would describe my personal relationships at the University of Louisville satisfying

$$
\begin{aligned}
& \square \text { Strongly Agree } \\
& \square \text { Agree } \\
& \square \text { Neutral } \\
& \square \text { Disagree } \\
& \square \text { Strongly Disagree }
\end{aligned}
$$

* 9. The University of Louisville embraces diversity

$$
\begin{aligned}
& \square \text { Strongly Agree } \\
& \square \text { Agree } \\
& \square \text { Neutral } \\
& \square \text { Disagree } \\
& \square \text { Strongly Disagree }
\end{aligned}
$$


* 10. I am a product of mentoring

$\square$ Strongly Agree

$\square$ Agree

$\square$ Neuiral

$\square$ Disagree

$\square$ Strongly Disagree

* 11. The University of Louisville's campus offers a variety of social groups which interests me

$\square$ Strongly Agree

$\square$ Agree

$\square$ Neutral

$\square$ Disagree

$\square$ Strongly Disagree

* 12 . I don't have a concrete support system

$\square$ Strongly Agree

$\square$ Agree

$\square$ Neutral

$\longrightarrow$ Disagree

$\square$ Strongly Disagree

* 13. I find it difficult to become involved

$\square$ Strongly Agree

$\square$ Agree

$\square$ Neutral

$\square$ Disagree

$\square$ Strongly Disagree 
* 14. I am often concerned about my image

$$
\begin{aligned}
& \square \text { Strongly Agree } \\
& \square \text { Agree } \\
& \square \text { Neutral } \\
& \square \text { Disagree } \\
& \square \text { Strongly Disagree }
\end{aligned}
$$

* 15. My values are not reflected on this campus

$$
\begin{aligned}
& \square \text { Strongly Agree } \\
& \square \text { Agree } \\
& \square \text { Neutral } \\
& \square \text { Disagree } \\
& \square \text { Strongly Disagree }
\end{aligned}
$$

* 16.1 often doubt myself before making decisions

$$
\begin{aligned}
& \square \text { Strongty Agree } \\
& \square \text { Agree } \\
& \square \text { Neutral } \\
& \square \text { Disagree } \\
& \square \text { Strongly Disagree }
\end{aligned}
$$

* 17. I feel comfortable with the racial climate on the University of Louisville's campus

$$
\begin{aligned}
& \square \text { Strongly Agree } \\
& \square \text { Agree } \\
& \square \text { Neutral } \\
& \square \text { Disagree } \\
& \square \text { Strongly Disagree }
\end{aligned}
$$

* 18.1 consider myself a student leader

$$
\begin{aligned}
& \square \text { Strongly Agree } \\
& \square \text { Agree } \\
& \square \text { Neutral } \\
& \square \text { Disagree } \\
& \square \text { Strongly Disagree }
\end{aligned}
$$


* 19. Peer mentoring is important to me

$\square$ Strongly Agree

$\square$ Agree

$\square$ Neutral

$\square$ Disagree

$\square$ Strongly Disagree

* 20. My mentees are a priority

Strongly Agree

$\square$ Agree

$\square$ Neutral

7 Disagree

Strongly Disagree

* 21. I am an effective peer mentor

Strongly Agree

$\square$ Agree

$\square$ Neutral

$\square$ Disagree

Strongly Disagree

* 22. I have established personal values

Strongly Agree

Agree

$\square$ Neutrai

Disagree

Strongly Disagree

* 23. My fellow CONECT peer mentors understand and share similar values
Strongly Agree
$\square$ Agree
Neutral
$\square$ Disagree
Strongly Disagree 
* 24. I don't feel safe on the University of Louisville's campus

$$
\begin{aligned}
& \square \text { Strongly Agree } \\
& \square \text { Agree } \\
& \square \text { Neutrai } \\
& \square \text { Disagree } \\
& \square \text { Strongty Disagree }
\end{aligned}
$$

* 25.1 am a focused individual

$$
\begin{aligned}
& \square \text { Strongly Agree } \\
& \square \text { Agree } \\
& \square \text { Neutrat } \\
& \square \text { Disagree } \\
& \square \text { Strongly Disagree }
\end{aligned}
$$

* 26 . I value the support of others

$$
\begin{aligned}
& \square \text { Sirongly Agree } \\
& \square \text { Agree } \\
& \square \text { Neutral } \\
& \square \text { Disagree } \\
& \square \text { Strongly Disagree }
\end{aligned}
$$

* 27. The University of Louisville encourages student support services

$$
\begin{aligned}
& \square \text { Sirongly Agree } \\
& \square \text { Agree } \\
& \square \text { Neutral } \\
& \square \text { Disagree } \\
& \square \text { Strongly Disagree }
\end{aligned}
$$




\section{Relationships with Advisors}

*1. CONECT Advisors are readily accessible

$$
\begin{aligned}
& \square \text { Strongly Agree } \\
& \square \text { Agree } \\
& \square \text { Neutral } \\
& \square \text { Disagree } \\
& \square \text { Strongly Disagree }
\end{aligned}
$$

* 2. I am not comfortable speaking with the CONECT Advisors

$$
\begin{aligned}
& \square \text { Strongly Agree } \\
& \square \text { Agree } \\
& \square \text { Neutral } \\
& \square \text { Disagree } \\
& \square \text { Strongly Disagree }
\end{aligned}
$$

* 3. CONECT Advisors provide sound advice

$$
\begin{aligned}
& \square \text { Strongly Agree } \\
& \square \text { Agree } \\
& \square \text { Neutral } \\
& \square \text { Disagree } \\
& \square \text { Strongly Disagree }
\end{aligned}
$$

* 4. CONECT Advisors have established great expectations for me

$$
\begin{aligned}
& \square \text { Strongly Agree } \\
& \square \text { Agree } \\
& \square \text { Neutral } \\
& \square \text { Disagree } \\
& \square \text { Strongly Disagree }
\end{aligned}
$$


*5. The CONECT Advisors understand me as an individual

$$
\begin{aligned}
& \square \text { Strongly Agree } \\
& \square \text { Agree } \\
& \square \text { Neutral } \\
& \square \text { Disagree } \\
& \square \text { Strongly Disagree }
\end{aligned}
$$

* 6. The CONECT Advisors foster a nurturing environment

$$
\begin{aligned}
& \square \text { Strongly Agree } \\
& \square \text { Agree } \\
& \square \text { Neutral } \\
& \square \text { Disagree } \\
& \square \text { Strongly Disagree }
\end{aligned}
$$

* 7. The CONECT Advisors have a positive influence on my personal growth

$$
\begin{aligned}
& \square \text { Strongly Agree } \\
& \square \text { Agree } \\
& \square \text { Neutral } \\
& \square \text { Disagree } \\
& \square \text { Strongly Disagree }
\end{aligned}
$$

* 8. The CONECT Advisors promote activities and time for self-reflections

$$
\begin{aligned}
& \square \text { Strongly Agree } \\
& \square \text { Agree } \\
& \square \text { Neutral } \\
& \square \text { Disagree } \\
& \square \text { Strongly Disagree }
\end{aligned}
$$

* 9. The CONECT Advisors provide me with personal and academic guidance

$$
\begin{aligned}
& \square \text { Strongly Agree } \\
& \square \text { Agree } \\
& \square \text { Neutral } \\
& \square \text { Disagree } \\
& \square \text { Strongly Disagree }
\end{aligned}
$$


* 10. The CONECT Advisors support my academic aspirations

$$
\begin{aligned}
& \square \text { Strongly Agree } \\
& \square \text { Agree } \\
& \square \text { Neutral } \\
& \square \text { Disagree } \\
& \square \text { Strongly Disagree }
\end{aligned}
$$

* 11. I will stay in contact with the CONECT Advisors regardless of my affiliation with the program

$$
\begin{aligned}
& \square \text { Strongly Agree } \\
& \square \text { Agree } \\
& \square \text { Neutral } \\
& \square \text { Disagree } \\
& \square \text { Sirongty Disagree }
\end{aligned}
$$

* 12. CONECT has provided me with exposure to faculty and staff

$$
\begin{aligned}
& \square \text { Strongly Agree } \\
& \square \text { Agree } \\
& \square \text { Neutral } \\
& \square \text { Disagree } \\
& \square \text { Strongly Disagree }
\end{aligned}
$$

\section{* 13. Academic advising has helped me a great deal}

$$
\begin{aligned}
& \square \text { Strongly Agree } \\
& \square \text { Agree } \\
& \square \text { Neutral } \\
& \square \text { Disagree } \\
& \square \text { Strongly Disagree }
\end{aligned}
$$


* 14. I have good rapport with the faculty and staff at the University of Louisville

Strongly Agree

$\square$ Agree

Neutral

$\square$ Disagree

$\square$ Strongly Disagree

* 15. Faculty and staff at the University of Louisville are genuinely concerned about the betterment of students

$\square$ Strongly Agree

$\square$ Agree

$\square$ Neutral

$\square$ Disagree

Strongly Disagree

* 16. I am comfortable relating to faculty and staff at the University of Louisville

$\square$ Strongly Agree

Agree

$\square$ Neutral

$\square$ Disagree

Strongly Disagree 


\section{Academic Integretion}

* 1. I have developed as an intellectual at the University of Louisville

$$
\begin{aligned}
& \square \text { Strongly Agree } \\
& \square \text { Agree } \\
& \square \text { Neutral } \\
& \square \text { Disagree } \\
& \square \text { Strongly Disagree }
\end{aligned}
$$

*2. I have high expectations of myself

$$
\begin{aligned}
& \square \text { Strongly Agree } \\
& \square \text { Agree } \\
& \square \text { Neutral } \\
& \square \text { Disagree } \\
& \square \text { Strongly Disagree }
\end{aligned}
$$

\section{* 3. Attendance in class is pointless}

$$
\begin{aligned}
& \square \text { Strongly Agree } \\
& \square \text { Agree } \\
& \square \text { Neutral } \\
& \square \text { Disagree } \\
& \square \text { Strongly Disagree }
\end{aligned}
$$

* 4 . I actively engage in class discussion

$$
\begin{aligned}
& \square \text { Strongly Agree } \\
& \square \text { Agree } \\
& \square \text { Neutral } \\
& \square \text { Disagree } \\
& \square \text { Strongly Disagree }
\end{aligned}
$$


* 5.1 am an intellectual

Strongly Agree

Agree

$\square$ Neutral

$\square$ Disagree

$\square$ Strongly Disagree

* 6. My academic record (i.e. transcript) is a reflection of me as an individual

$\square$ Strongly Agree

$\square$ Agree

$\square$ Neutral

$\square$ Disagree

$\square$ Strongly Disagree

* 7. I often forget the materials I learn

Strongly Agree

$\square$ Agree

$\square$ Neutral

$\square$ Disagree

$\square$ Strongly Disagree

* 8. I have to work much harder than everyone else
Strongly Agree
$\square$ Agree
$\square$ Neutrat
$\square$ Disagree
Strongly Disagree

* 9.1 frequently think about quitting school

Strongly Agree

Agree

$\square$ Neutral

$\square$ Disagree

Strongly Disagree 


\section{* 10. My academic record is a reflection of my effort}

$$
\begin{aligned}
& \square \text { Strongly Agree } \\
& \square \text { Agree } \\
& \square \text { Neutral } \\
& \square \text { Disagree } \\
& \square \text { Strongly Disagree }
\end{aligned}
$$

* 11. Learning something new is exciting

$$
\begin{aligned}
& \square \text { Strongly Agree } \\
& \square \text { Agree } \\
& \square \text { Neutral } \\
& \square \text { Disagree } \\
& \square \text { Strongly Disagree }
\end{aligned}
$$

* 12.1 am motivated by grasping new concepts

$$
\begin{aligned}
& \square \text { Strongly Agree } \\
& \square \text { Agree } \\
& \square \text { Neutrai } \\
& \square \text { Disagree } \\
& \square \text { Strongly Disagree }
\end{aligned}
$$

* 13. I have been exposed to a number of new ideas and concepts

$$
\begin{aligned}
& \square \text { Strongly Agree } \\
& \square \text { Agree } \\
& \square \text { Neutrai } \\
& \square \text { Disagree } \\
& \square \text { Strongly Disagree }
\end{aligned}
$$

\section{* 14. Classes have not been stimulating}

$$
\begin{aligned}
& \square \text { Strongly Agree } \\
& \square \text { Agree } \\
& \square \text { Neurrat } \\
& \square \text { Disagree } \\
& \square \text { Strongly Disagree }
\end{aligned}
$$




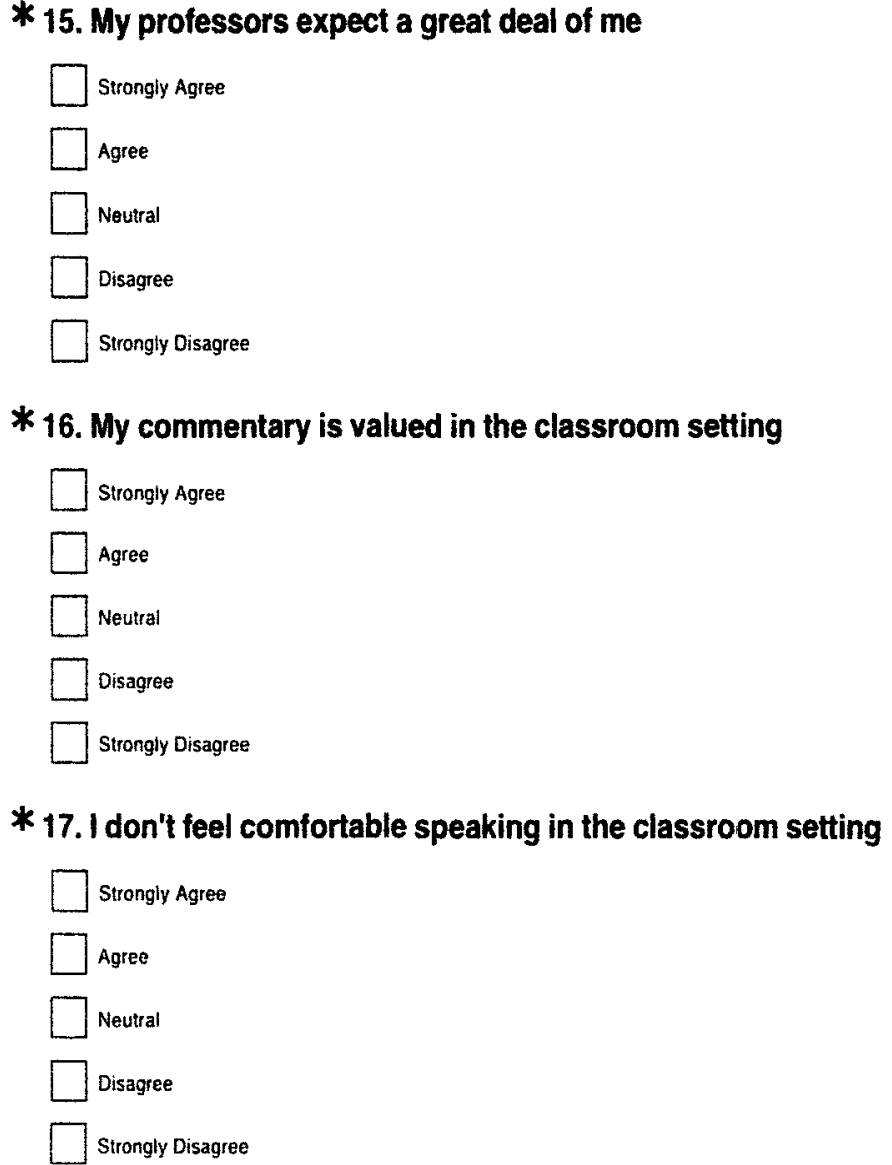

* 16. My commentary is valued in the classroom setting

$\square$ Strongly Agree

Agree

Teutral

Disagree

Strongly Disagree

* 17.1 don't feel comfortable speaking in the classroom setting

$\square$ Strongly Agree

$\square$ Agree

$\square$ Neutral

$\square$ Disagree

Strongly Disagree

* 18. Sometimes l experience anxiety in the classroom setting

Strongly Agree

$\square$ Agree

Neutra!

Disagree

Strongly Disagree 


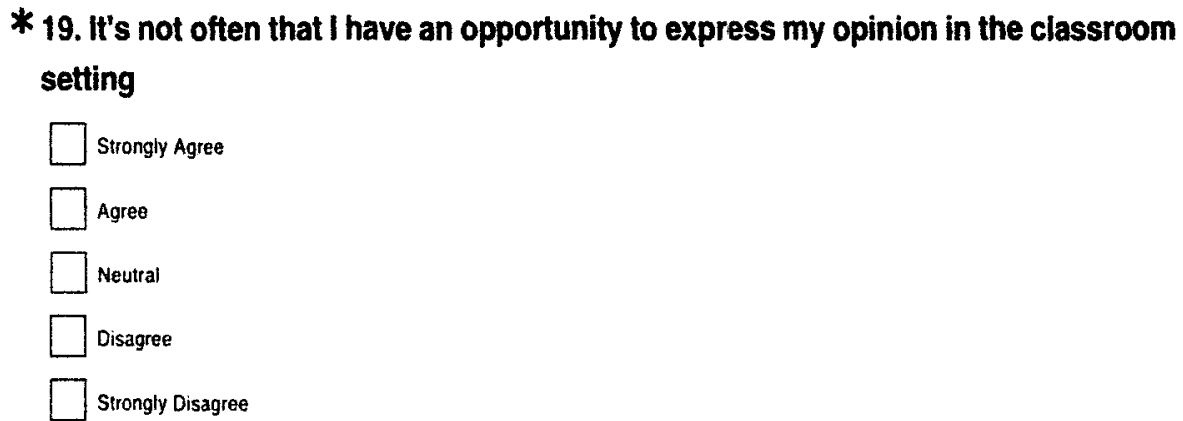

* 20 . I am overwhelmed by classroom expectations

$\square$ Strongly Agree

$\square$ Agree

$\square$ Neutral

$\square$ Disagree

$\square$ Strongly Disagree

* 21. I find it difficult to pay attention in class

$\square$ Strongly Agree

$\square$ Agree

$\square$ Neutra!

$\square$ Disagree

$\square$ Strongly Disagree

* 22.1 often second guess myself before speaking in class

$\square$ Strongly Agree
$\square$ Agree
$\square$ Neutral
$\square$ Oisagree
$\square$ Strongly Disagree


* 23. Graduation equates to success

$\square$ Strongly Agree

$\square$ Agree

$\square$ Neutral

$\square$ Disagree

$\square$ Strongly Disagree

* 24 . I am expected to graduate

$\square$ Strongly Agree

$\square$ Agree

Neutral

$\square$ Disagree

$\square$ Strongly Disagree

* 25. Graduation will be a major accomplishment

Strongly Agree

$\square$ Agree

$\square$ Neutral

$\square$ Disagree

$\square$ Strongly Disagree

* 26. Graduation is motivation

$\square$ Strongly Agree

$\square$ Agree

$\square$ Neutral

$\square$ Disagree

$\square$ Strongly Disagree

* 27. I understand my learning styje

$\square$ Strongly Agree

$\square$ Agree

$\square$ Neutral

$\square$ Disagree

$\square$ Strongly Disagree 


$$
\begin{aligned}
& \text { * } 28 . \text { I always perform poorly on exams } \\
& \square \text { Strongly Agree } \\
& \square \text { Agree } \\
& \square \text { Neutral } \\
& \square \text { Disagree } \\
& \square \text { Strongly Disagree }
\end{aligned}
$$

* 29. My academic goals are outlined

$\square$ Strongly Agree

$\square$ Agree

$\square$ Neutral

$\square$ Disagree

$\square$ Strongly Disagree

* 30. I have had a positive academic experience at the University of Louisville

$$
\begin{aligned}
& \square \text { Strongly Agree } \\
& \square \text { Agree } \\
& \square \text { Neutral } \\
& \square \text { Disagree } \\
& \square \text { Strongly Disagree }
\end{aligned}
$$$$
\text { Neutral }
$$

* 31. Academic success is my first priority

$$
\begin{aligned}
& \square \text { Strongly Agree } \\
& \square \text { Agree } \\
& \square \text { Neurral } \\
& \square \text { Disagree } \\
& \square \text { Strongly Disagree }
\end{aligned}
$$

\section{* 32. I have yet to choose my major}

Strongly Agree

$\longrightarrow$ Agree

$\square$ Neutral

$\square$ Disagree

Strongly Disagree 


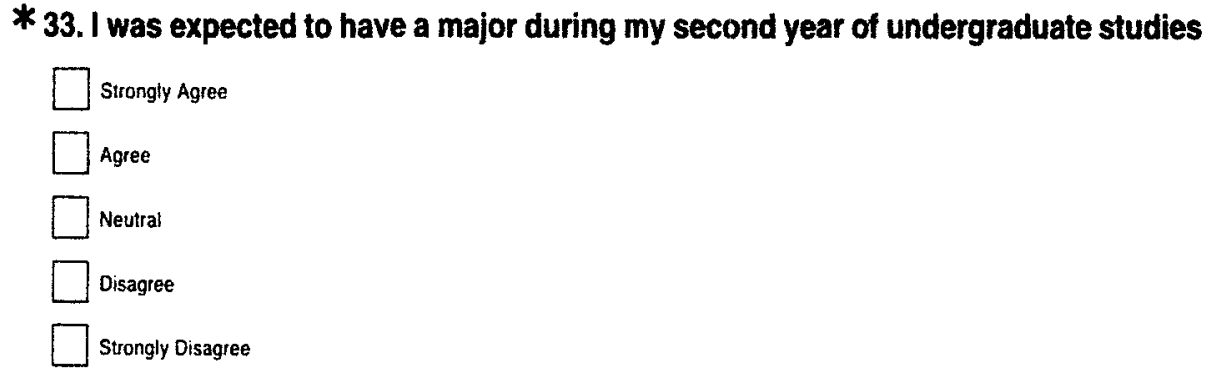

* 34. Selecting a major was overwhelming

$$
\begin{aligned}
& \square \text { Strongly Agree } \\
& \square \text { Agree } \\
& \square \text { Neutral } \\
& \square \text { Disagree } \\
& \square \text { Strongly Disagree }
\end{aligned}
$$

* 35. I am comfortable with the decision I made regarding my major

$$
\begin{aligned}
& \square \text { Strongly Agree } \\
& \square \text { Agree } \\
& \square \text { Neutrat } \\
& \square \text { Disagree } \\
& \square \text { Strongly Disagree }
\end{aligned}
$$

* 36 . I thoroughly enjoy my courses in my major

$$
\begin{aligned}
& \square \text { Strongly Agree } \\
& \square \text { Agree } \\
& \square \text { Neutral } \\
& \square \text { Disagree } \\
& \square \text { Strongly Disagree }
\end{aligned}
$$

\section{* 37. I had no direction when selecting a major}

$$
\begin{aligned}
& \square \text { Strongly Agree } \\
& \square \text { Agree } \\
& \square \text { Neutral } \\
& \square \text { Disagree } \\
& \square \text { Strongly Disagree }
\end{aligned}
$$




\section{* 38. Choosing a major is not important for me at this time}

$$
\begin{aligned}
& \square \text { Strongly Agree } \\
& \square \text { Agree } \\
& \square \text { Neutral } \\
& \square \text { Disagree } \\
& \square \text { Strongly Disagree }
\end{aligned}
$$

* 39. Graduating is a major priority

$$
\begin{aligned}
& \square \text { Strongly Agree } \\
& \square \text { Agree } \\
& \square \text { Neutrai } \\
& \square \text { Oisagree } \\
& \square \text { Strongly Disagree }
\end{aligned}
$$

\section{* 40 . I will graduate from the University of Louisville}

$$
\begin{aligned}
& \square \text { Strongly Agree } \\
& \square \text { Agree } \\
& \square \text { Neutral } \\
& \square \text { Disagree } \\
& \square \text { Strongly Disagree }
\end{aligned}
$$




\section{APPENDIX D}

Interview Questions for Peer Mentors

1. Why did you become a peer mentor and what was your previous experience with peer mentoring?

2. How beneficial was your mentoring experiences?

3. Did you do anything to establish a relationship with your mentees?
a. If so, what?
b. Were your methods beneficial to your mentees?

4. Did you find peer mentoring to be rewarding?

a. If so, how?

5. What were some of the challenges you faced as a peer mentor?

6. How were able to overcome your challenges?

7. Did you receive academic and personal support as a peer mentor? Please explain.

8. Describe your relationship with:
a. Fellow CONECT peer mentors
b. CONECT Advisors

9. Have you developed since becoming a CONECT peer mentor?

a. How? (i.e. socially, academically, analytically, etc)

10. Please compare and contrast the differences between the CONECT peer mentoring community and campus as a whole?

11. Upon acceptance as a CONECT peer mentor, did your performance in the classroom change (i.e. attendance, participation, interaction with professors and classmates)?

a. Outside the classroom?

12. Do you feel a part of the University of Louisville's campus?

a. Explain. 
13. What is your primary goal as a student at the university?

14. What have you done to reach that goal? 


\section{APPENDIX E \\ Follow up Questions for Non-Mentors}

1. What was your previous experience with mentoring?

a. Peer mentoring?

b. Did you find your mentoring experiences to be beneficial? Explain.

2. What challenges did you face as a student?

3. What support did you receive as a student?

4. Did you hold any leadership roles on campus?

5. Did your performance in the classroom change during your second year? (i.e. attendance, participation, interaction with professors and classmates)

a. Outside the classroom?

6. How did you establish balance between academic obligations, leadership/extracurricular activities and personal needs?

7. Did you develop as a student during your second year? How?

8. What is/were your attitude towards your third (junior) year of studies at the University of Louisville?

9. Do you feel connected to the University of Louisville?

a. Explain. 


\section{CURRICULUM VITAE}

\section{Tiffany Christina Evans, MA Candidate}

4329 Lahnna Drive

Louisville, KY 40216

Email: Tiffany.Evans01@gmail.com

\section{Education}

M.A.

B.A.

\section{Study Abroad}

Summer 2010

Summer 2009

Summer 2008
Pan-African Studies (December 2011)

Concentration: African Americans in Higher Education

University of Louisville, Louisville, KY

Thesis: Combating the Sophomore Slump through PeerMentoring Among African American Students at Predominately White Institutions

There is a plethora of research regarding the first year undergraduate student experience; however, 2 nd year students are facing adversity and consequently high rates of attrition. This phenomenon is known as the sophomore slump. There is limited research of how the sophomore slump impacts African Americans and research supports involvement, particularly as a peer mentor, increases student persistence beyond the 2nd year. This study uses Tinto's theory of student departure and Collin's theory of othermothering to explore how the academic and social skills of CONECT peer mentors contribute to their experiences as peer mentors and their overall persistence.

Pan-African Studies, (May 2009)

Minor: Latin American Studies

University of Louisville, Louisville, KY
Service Learning in Botswana, Africa

University of the West Indies - St. Augustine, Trinidad \& Tobago

University of Louisville in Panama: Panama City, Panama 


\section{Academic Awards}

2010-2011 Graduate Assistant, Department of Pan-African Studies, University of Louisville

Spring $2009 \quad$ Nancy Pollock Award for Outstanding Undergraduate, Department of Pan-African Studies, University of Louisville

2005-2008 Woodford R. Porter Scholarship Recipient

University of Louisville

Experience

Teaching

Teaching Assistant, Department of Pan-African Studies

University of Louisville, 2010

PAS 332-01: African-American Women - WR, Fall 2010 semester

PAS 333-01: Black Student Experience, Spring 2010 semester

\section{Service}

$2007-2010$

Outreach Program Facilitator, Girl Scouts of Kentuckiana

2008

Intern, Iroquois Public Library, Louisville, Kentucky

2007

Executive Vice President, Society of Porter Scholars, University of Louisville

2006-2008

Peer mentor, College of Arts and Sciences, University of Louisville

2006-2007

Conference Assistant, Housing and Residence Life, University of Louisville

2006

First Year Guide, Housing and Residence Life, University of Louisville

\section{References}

Confidential dossier available through Interfolio and will be sent under separate cover.

The following individuals have written letters of recommendation on my behalf: 
Dr. Tomarra Adams, Assistant Professor

Pan-African Studies Department

University of Louisville

434 Strickler Hall

Louisville, KY 40208

(502) 852-3077

taadam01@louisville.edu

Mr. Christopher L. Johnson, Associate Administrator

Area Health Education Center

University of Kentucky

138 Leader Avenue

Lexington, KY 40506

(859) 323-8018

chris.johnson@uky.edu

Mary S. Joshua, Associate Director of Minority and Rural Affairs

Health Sciences Center

University of Louisville

323 E. Chestnut St $[$ ]

Louisville, KY 40292

(502) 852-7159

mary.joshua@1ouisville.edu 